\title{
Instrumentation Studies of Earth Tremors Related to Geology and to Mining at the Somerset Coal Mine, Colorado
}

GEOLOGICAL SURVEY PROFESSIONAL PAPER 762 


\section{Instrumentation Studies of Earth Tremors Related to Geology and to Mining at the Somerset Coal Mine, Colorado}

By FRANK W. OSTERWALD, C. RICHARD DUNRUD,

JOHN B. BENNETTI, JR., and JOHN O. MABERRY

G E O L O G I A A L U R V E Y P R O FE S I O N A L P A P E R 762

The relation of bedrock and surficial geology, coal mining, and a nuclear explosion to tremors in part of the Grand Mesa coal field, Colorado

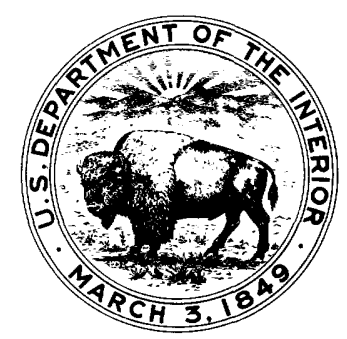




\section{UNITED STATES DEPARTMENT OF THE INTERIOR}

ROGERS C. B. MORTON, Secretary

GEOLOGICAL SURVEY

V. E. McKelvey, Director

Library of Congress catalog-card No. 72-600237

For sale by the Superintendent of Documents, U.S. Government Printing Office Washington, D.C. 20402-Price 70 cents (paper cover) Stock Number 2401-00227 


\section{CONTENTS}

Abstract

Introduction...

Acknowledgments.

Geology

Coal mining
Page

Seismic work in the Somerset district...

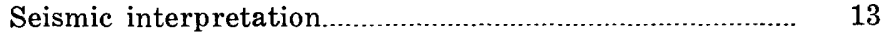

Effects of nuclear explosions........................................ 19

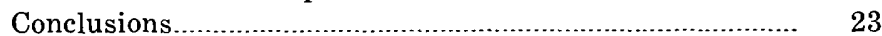

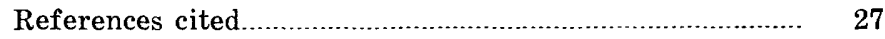

\section{ILLUSTRATIONS}

2. Part of western Colorado.

3. Somerset mining district and vicinity

4. Somerset mining district and generalized mine workings.

5. Photograph of moraine along Hubbard Creek

6. Block diagram of field instrumentation system used in Somerset mining district.

7. Graph showing frequency response of preamplifiers.

8. Photograph showing arrangement of field instrumentation.

9. Graph showing frequency response of FM magnetic tape recorder (storage system) and paper recorder (real-time system)

10. Schematic diagram of photocell-activated chronograph circuit.

11. Graph showing total elapsed time of the monitoring period and actual recording time.

12. Calibration seismogram of station $D$

13. Graph showing frequency response of the EV-17 seismometer

14-20. Seismograms:

14. First type of tremor, recorded by mobile network........

15. Second type of tremor, recorded by mobile network

16. Third type of tremor, recorded by mobile network

17. First type of tremor, recorded by fixed station.

18. Second type of tremor, recorded by fixed station

19. Sonic boom from jet aircraft, recorded by fixed station

20. Tremor of long wave train with high-frequency compressional waves and low-frequency late phases, recorded by fixed station.

21-23. Semilogarithmic plots:

21. Number of tremors per day recorded by mobile network and at fixed stations, and times when no mining work was being done..

22. Number of large tremors per day

23. Seismic activity summed for 3 -hour periods

24. Oscillogram of the first motion from the RULISON explosion.

25. Oscillogram of calibration signal injected into preamplifier before RULISON explosion.

26-30. Seismograms:

26. Shock waves from the RULISON explosion, near Grand Valley, recorded by mobile network..

27. Nuclear explosion in Nevada, recorded by mobile network

28. Nuclear explosion in Nevada, recorded by fixed station.

29. Two small earthquakes, recorded by mobile network

30. Two small earthquakes, recorded by fixed station. 



\title{
INSTRUMENTATION STUDIES OF EARTH TREMORS RELATED TO GEOLOGY AND TO MINING AT THE SOMERSET COAL MINE, COLORADO
}

\author{
By Frank W. Osterwald, C. Righard Dunrud, \\ John B. Bennetti, Jr., and John O. Maberry
}

\begin{abstract}
A temporary seismic recording network was operated for about 2 weeks in the fall of 1969 on the ground surface around the Somerset coal mine, in Delta and Gunnison Counties, Colo., to study seismic activity as related to coal mining and geology. Tremors, most of which were small manmade earthquakes, were recorded both on chart paper and on magnetic tape with sufficient precision that we could locate most hypocenters within 750 feet of their true position. Nearly all the tremors originated within 1 mile of the actively mined parts of the Somerset mine and between 1,000 feet and 6,000 feet below the mine. Some tremors occurred directly beneath the mine; others occurred along a line west of the mine beneath the intersection of a southeastward-trending zone of steep dip in coal and several northward-trending clastic dikes. The line of tremor hypocenters, which is parallel to and beneath the east wall of the canyon of Hubbard Creek, is probably a result of stresses which, differentially concentrated in the zone of steep dip and the dikes by mining, were released and redistributed as underground mining progressed. The rapid lateral change of overburden stress along the canyon may have induced failures as stresses were redistributed by mining. Although the distribution of hypocenters clearly was related spatially to actively mined areas, no direct correlation between the rate of tremor occurrences recorded by the network and mining work cycles was observed during the monitoring period. A fixed station located above the Somerset mine, however, recorded many local tremors, and rates of tremor occurrence detected by it are related to mining work cycles.

A nuclear explosion detonated 41 miles northwest of Somerset during the monitoring period apparently influenced the occurrence pattern of large tremors recorded by the network but did not influence the occurrence pattern of all tremors and did not disrupt the mining.
\end{abstract}

\section{INTRODUCTION}

Coal has been mined near Somerset, in Delta and Gunnison Counties, Colo., for many years. Coal mine bumps, which are violent, spontaneous, and destructive bursts of coal and rock from mine ribs, faces, floors, and roofs, are a hazard in the Somerset coal mine (fig. 1). Other failures of mine workings, such as heaving floors, pots (sudden release of inverted cone-shaped masses of coal and rock from roofs), and cave-ins, some of which may be caused by mechanisms similar to those causing bumps, occur in the Somerset mine. The U.S. Geological Survey began a research program in 1968 to study these mining hazards at Somerset as part of a continuing investigation of geologic factors that influence bumps and other failures of mine workings (Osterwald and Dunrud, 1966). Most research to date has been done at Sunnyside, Utah; short-term monitoring experiments also have been conducted elsewhere in Utah (Osterwald and others, 1971).

To aid the program, a continuously recording seismograph, with one vertical component seismometer, was installed at Somerset in July 1969. During the first month the seismograph recorded 1,000 small tremors in and around the mine. Consequently, an experiment was planned to use a mobile, temporary seismic array to locate hypocenters of these tremors and to study the relation of the tremors to geologic features and mining. To obtain the maximum information from the recording experiment, we planned to record during a nuclear explosion (project RULISON) scheduled to be detonated beneath Battlement Mesa, near Grand Valley, about 41 miles northwest of Somerset (figs. 1, 2). The minimum recording period was to begin 1 week before and end 1 week after the explosion so that any resultant changes in seismic activity in or near the mine could be detected.

The Somerset mining district as designated by Lee $(1912$, p. 67-68) is on the southeast flank of Grand Mesa, a large flat-topped mountain with a maximum elevation of 10,800 feet (fig. 2) that is capped by remnants of Pliocene basalt flows (Yeend, 1969 , p. 8). Below the caps of basalt are thick beds of claystone, siltstone, shale, and sandstone of Tertiary age which are weak and are prone to largescale mass movements; these Tertiary rocks make up much of the upland part of the Somerset district (fig. 3). 
The Somerset district is about 60 miles eastsoutheast of Grand Junction (fig. 1). The towns of Somerset and Bowie, both owned originally by coal mining companies, are the only organized settlements in the district. Paonia, 9 miles by road west of the Somerset mine, is the residential and business center for much of the area surrounding the district. A paved road, Colorado State Highway 133, connects the district with the towns of Hotchkiss and Delta; this highway is partly paved to the east, connecting the district, by way of McClure Pass, with Redstone and Glenwood Springs. A branch of the Denver and Rio Grande Western Railroad from Grand Junction provides freight service, by way of Delta, to Hotchkiss, Paonia, Bowie, and Somerset, as well as to a few small coal mines.

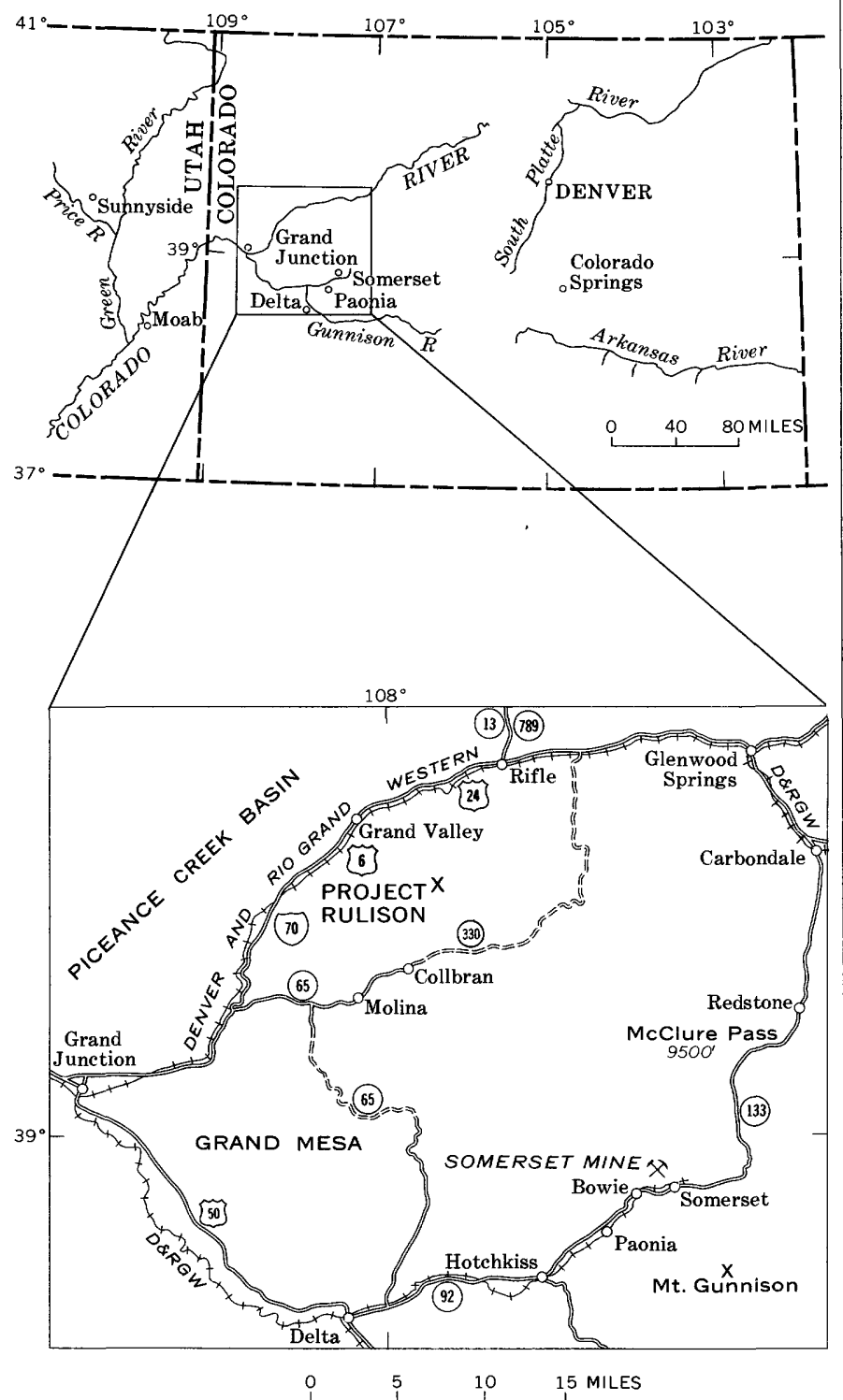

Figure 1. - Index map of Colorado.
Coal beds in the district crop out along both sides of the North Fork of the Gunnison River, which flows westward at the town of Somerset, and along some of the tributary canyons (fig. 3). The river at Somerset is at an elevation of about 6,000 feet and is 3,800 feet below mountain summits 5 miles to the north.

This report describes briefly the instruments in the mobile system, especially those that were modified after similar monitoring experiments were done in Utah (Osterwald and others, 1971). The geology of the Somerset district also is described briefly, particularly as it pertains to coal mining and to seismic activity.

Responsibility for aspects of the work was shared by the authors. Dunrud and Osterwald planned the monitoring experiment and set design limits for the instrumentation, and Dunrud located the instrument sites. Bennetti designed and modified some of the instrumentation for the particular conditions expected during the monitoring period. Bennetti also supervised the assembly and installation of the equipment, calibrated the entire system, and supervised its operation. Dunrud determined tremor hypocenters, calculated ground-motion parameters of the nuclear explosion, and supplied much of the geologic information. Maberry and Osterwald helped install and remove the network and assisted in its operation at times.

\section{ACKNOWLEDGMENTS}

We thank many individuals who directly or indirectly aided the investigation. R. M. Case, of the U.S. Forest Service, gave permission to use National Forest land and permitted us to use the Forest Service radio network for emergency communications. Russell W. Ramey allowed ready access to lands and facilities controlled by his company at Somerset. Owen Jacobs granted us permission to install signal wires and to locate the recording van and supporting camp on his property in Condemn It Park. Jerome Hernandez and Theron E. Miller worked many long hours under very difficult field conditions to make the study a success. Ray W. Osterwald voluntarily helped to install the system and to remove it quickly because of threatening weather.

\section{GEOLOGY}

Coal, most of which comes from a bed known locally as the Somerset or B bed, is mined at Somerset from the lower part of the Mesaverde Formation (Upper Cretaceous), a complexly interfingering unit of transgressive and regressive littoral-marine to continental strata. This coal bed is one of five major coal beds contained in an interbedded and lenticular sandstone and shale sequence 250-300 


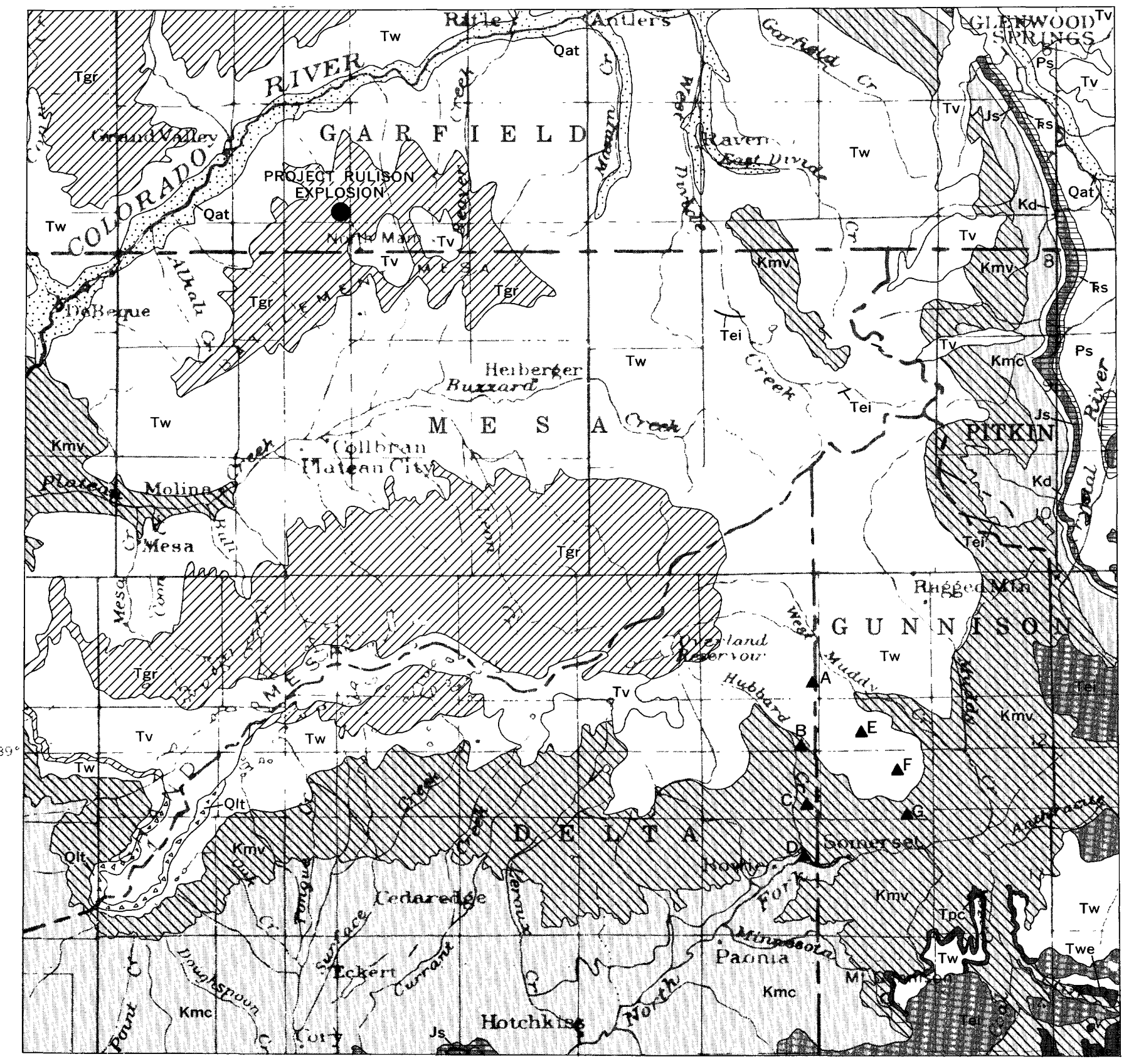

10

20 MILES

Figure 2. -- Geologic map of part of western Colorado, showing sites of mobile seismic stations (solid triangles) and of RULISON explosion (solid dot). Modified from geologic map of Colorado (Burbank and others, 1935). Kd, Dakota (?) Sandstone, Kmc, Mancos Shale, and Kmv, Mesaverde Formation, of Cretaceous age; Tw, Wasatch Formation, Tgr, Green River Formation, Tei, intrusive rocks, and Tv, extrusive rocks, of Tertiary age; Qtg, terrace gravels of Quaternary age.

feet thick. This unit, which was termed the lower coal member of the Mesaverde Formation by Johnson (1948), overlies a conspicuous cliff-forming white to light-yellow-brown sandstone, 150 feet to more than 200 feet thick, that was called the Rollins Sandstone Member by both Lee (1912, p. 30-32) and
Johnson (1948). The Rollins overlies several thousand feet of Mancos Shale.

The so-called upper coal member of the Mesaverde Formation overlies the lower coal member and resembles the lower member lithologically except that the upper is more lenticular (Johnson, 1948). The 


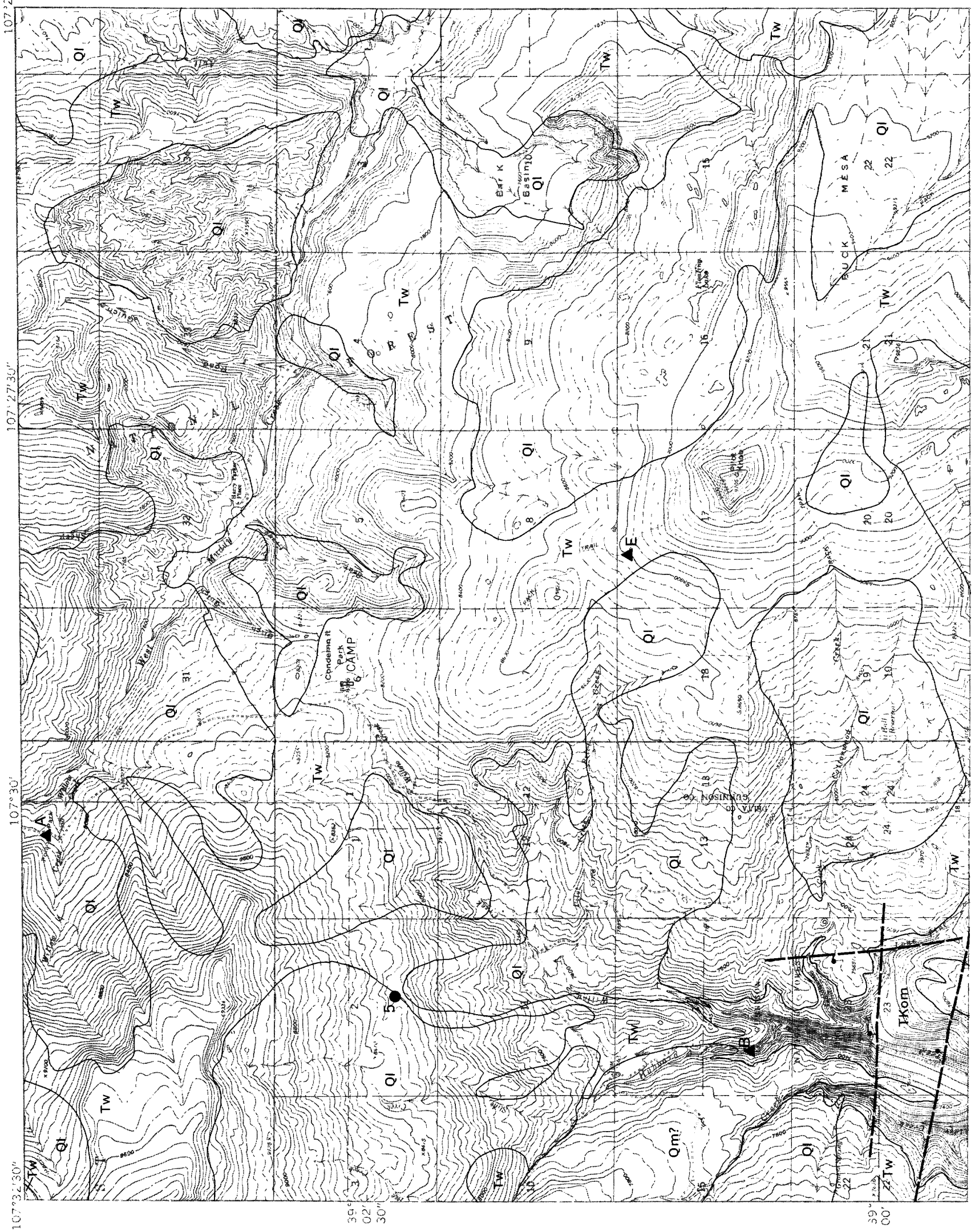









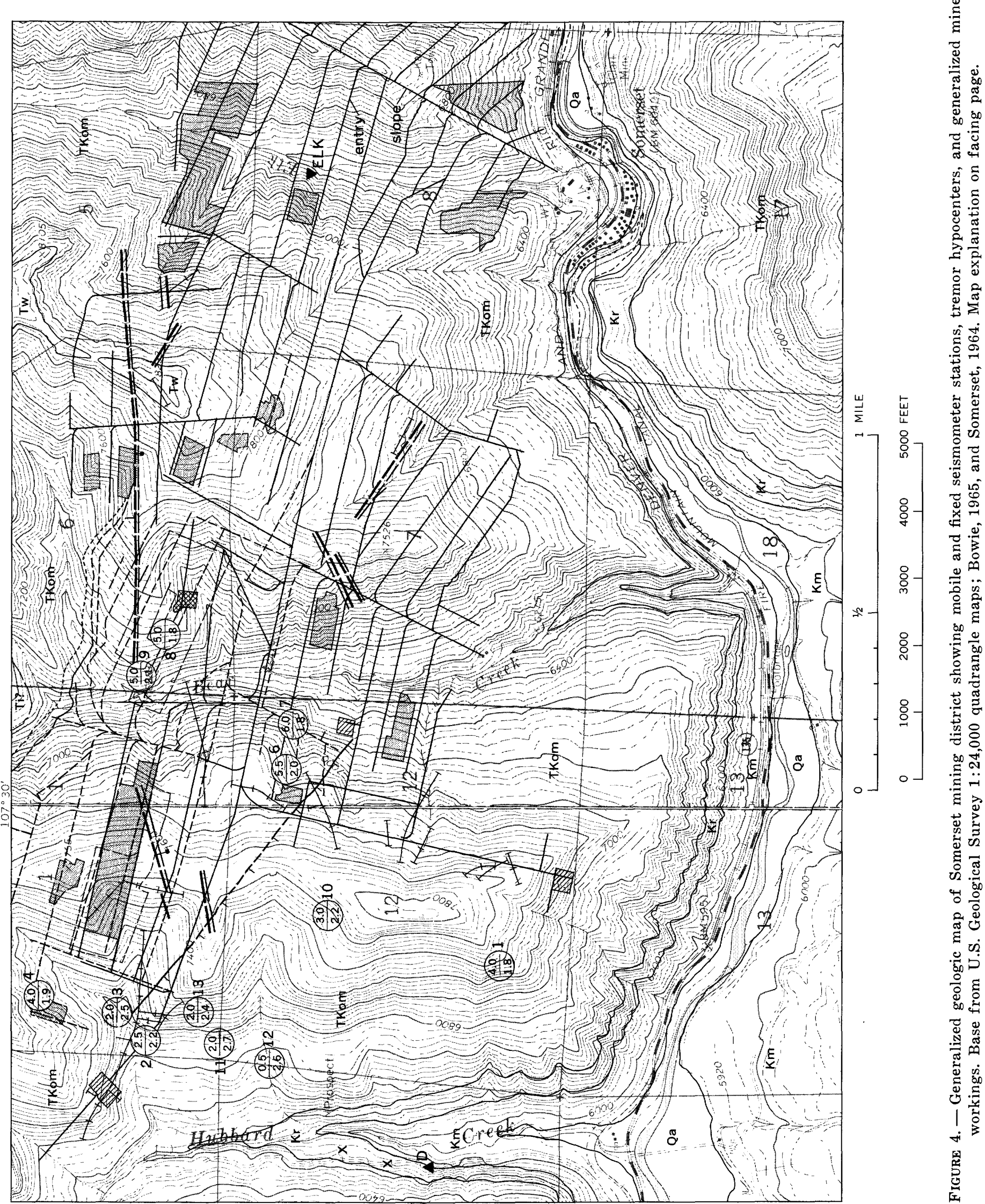



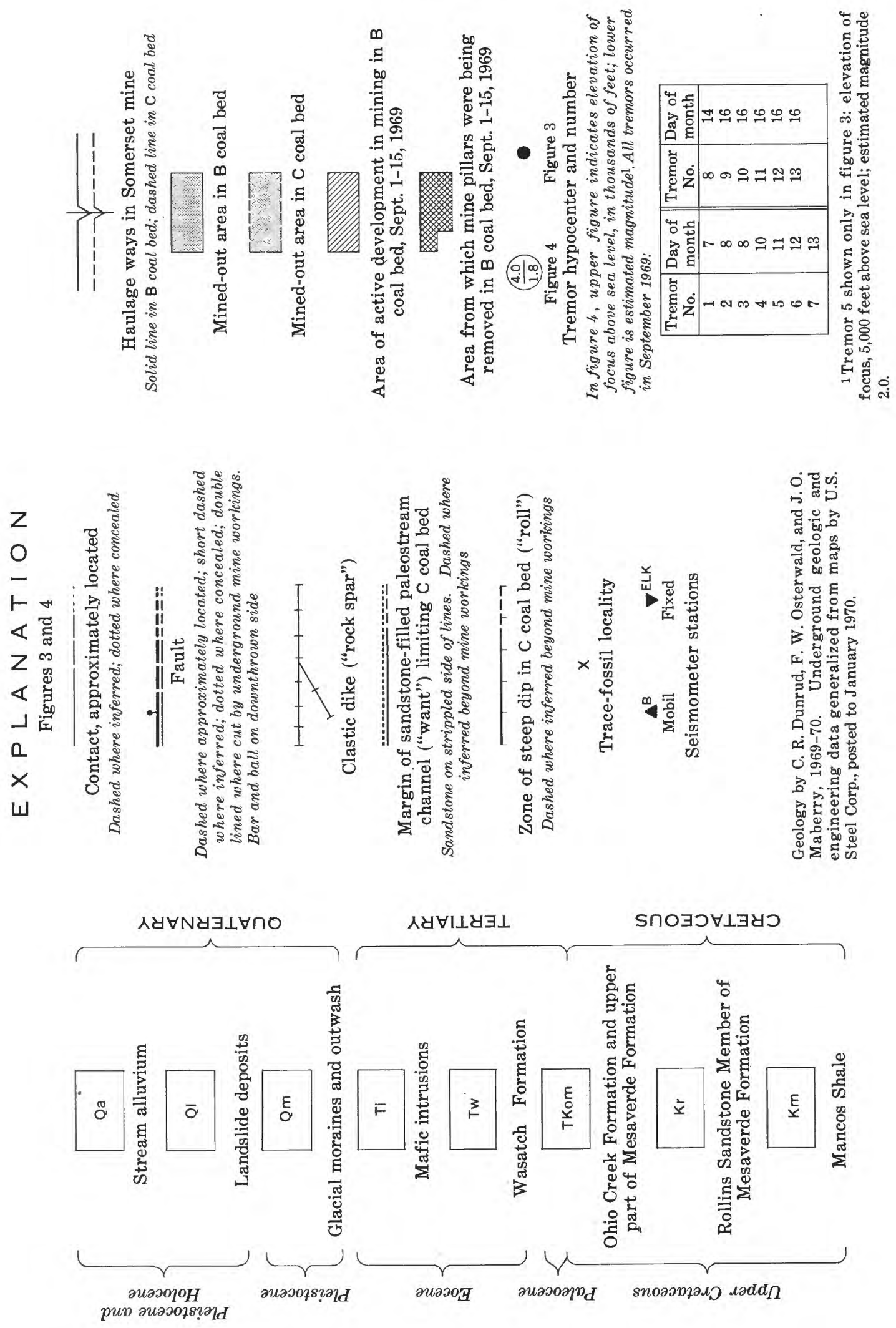
upper is as much as 400 feet thick and includes four coal beds and a thick but lenticular uppermost sandstone bed. Lee (1912, p. 32-43) called the lower coal member the Bowie Shale Member (marine and brackish-water origin) and the upper coal member the Paonia Shale Member (nonmarine origin); however, Johnson (1948) found marine rocks in Lee's Paonia Shale Member and nonmarine rocks in Lee's Bowie Shale Member, and consequently he did not use the names. About 1,200 feet of non-coalbearing lenticular and interbedded sandstone and shale that Johnson (1948) termed the barren member of the Mesaverde Formation lies above the upper coal member.

Many of the sandstones of the Mesaverde Formation in the Somerset district locally contain numerous fossils, termed Halymenites major by both Lee (1912) and Johnson (1948), that are actually trace fossils called Ophiomorpha, domicile burrows constructed by decapod crustaceans in marine sediments of a shallow neritic zone during withdrawal of the Mancos Sea. Other trace fossils found in cursory examinations of the shallow marine Mesaverde rocks below the coal beds include Thalassinoides and Asterosoma. Large horizontal burrows, thought to be those of Planolites montanus, and rare gastropod trails of undetermined taxonomy were found in mudstone beds and siltstone beds above the coal zone. These trace fossils, which are similar to those described from the Mesaverde rocks at Sunnyside, Utah (Maberry, 1971, p. 10-17, 26-30), probably indicate continental depositional environments.

A unit comprising beds of lenticular sandstone, conglomerate, shale, and mudstone of Paleocene age, called the Ohio Creek Formation by Gaskill and Godwin (1963), overlies the Mesaverde Formation. Because the Ohio Creek and Mesaverde are lithologically similar, they make a distinctive topographic unit below the Wasatch Formation; consequently, they are shown together in figures 3 and 4 . The Mesaverde and Ohio Creek are difficult to separate in the district, particularly where sandstones are thin or absent at the base of the Ohio Creek Formation. The basal sandstones, where present, are more friable, coarser grained, less calcareous, and lighter colored than the sandstones of the Mesaverde. The basal part of the Ohio Creek rarely contains conglomerate, but rounded granules, pebbles, and varicolored chert and quartzite cobbles occur locally in sandstones near the top.

The Wasatch Formation, a thick unit of varicolored claystone and siltstone beds that contain lenses of sandstone and conglomerate of Eocene age, overlies the Ohio Creek (figs. 3, 4). Claystone is the dominant rock type in the Wasatch. Volcanic and plutonic rock fragments, as well as fragments from the Ohio Creek Formation, are common near the base. The abundant volcanic debris in the Wasatch, including gravels, cobbles, and tuffaceous materials, causes most unpaved roads to become rough, slick, and almost impassable, even for fourwheel-drive vehicles, during wet weather.

Quaternary sediments of various types are abundant in the Somerset district. Alluvial sands, silts, and gravels fill the valley of the North Fork of the Gunnison River, and remnants of alluvial terraces at elevations up to several hundred feet above the river occur on the valley walls west of Somerset. Highland areas north of the North Fork, where some of the seismic instruments were installed, are covered with thick soil. Slopes are so heavily mantled with colluvium and landslide debris that only a few outcrops can be seen above 7,500 feet elevation.

A mass of unsorted debris ranging in size from silt to subangular boulders near the confluence of Hubbard and Willow Creeks probably is part of a terminal or lateral moraine (figs. 3,5 ). The base of the mass is at an elevation of about 7,400 feet and is about 120 feet above Hubbard Creek, which flows in a narrow $V$-shaped gulch entrenched into a broad valley at that point. Although we do not know that the mass is actually till, Pleistocene glaciers reached elevations as low as 5,400 feet on the north side of Grand Mesa (Yeend, 1969, p. 22), and hence they could have reached 7,400 feet on the south side. Thick surficial cover in the district made proper installation of seismometers on bedrock very difficult.

Numerous sills, laccoliths, dikes, and other intrusive masses were emplaced in the coal-bearing rocks after deposition of the Wasatch Formation (Eocene) (Lee, 1912, p. 52-53). The largest of these masses

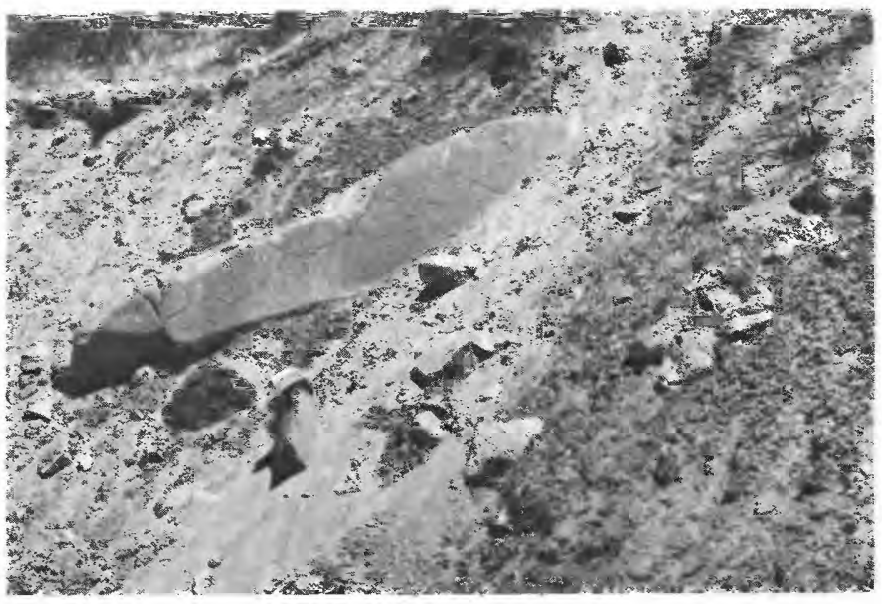

Figure 5. - Moraine along Hubbard Creek. Hat near center of picture below large boulder indicates scale. Many boulders are striated. 
makes up Mount Gunnison, a prominent peak about 7 miles southwest of Somerset. According to Lee (1912, p. 52-56) most of the igneous rocks are quartz monzonite porphyry. The largest mass of igneous rock in the Somerset district is an irregular mafic intrusion several hundred feet thick which is in the barren member of the Mesaverde Formation at Iron Point (fig. 3), high on the west side of the canyon of Hubbard Creek. Small irregular clastic dikes, called rock spars by miners, that were injected into fractures at low temperatures are common in the Somerset mine. A small mass of intrusive breccia was found in the canyon of Bear Creek 1 mile west of Somerset.

Geologic structure in the Somerset district is simple. Coal beds at the Somerset mine dip north and northeast at about 500 feet per mile, although a gentle northeast-trending anticlinal nose extends into the north-central part of the district (Johnson, 1948). Neither Lee (1912) nor Johnson (1948) mapped faults; however, several steeply dipping faults occur north and east of the Somerset mine (fig. 3). These faults trend west-northwest to eastnortheast and have stratigraphic separations of 5-20 feet. A few steeply dipping faults which trend westnorthwest to east and have stratigraphic separations of a few feet offset the coal in the mine. Clastic dikes probably were injected into some irregular fractures of about the same age and trend as these faults. Other faults, which have various dips and trends, occur in the northern part of the mine, in both the $\mathrm{B}$ and $\mathrm{C}$ coal beds. These faults may be part of a deformation zone around a probable intrusive mass beneath the canyon of Bear Creek (figs. 3, 4). An irregular channel sandstone, called a want by miners, truncates the $\mathrm{C}$ coal bed along the north limit of the mine, and a zone of steep dip truncates the $\mathrm{C}$ bed along the south limit (figs. 3, 4). The zone of steep dip may have resulted from differential compaction around a thick sandstone-filled channel below the $\mathrm{C}$ bed and south of the south limit of the mine. Areas of numerous slickensided fractures are common in coal near the sandstones and locally create hazardous mine roofs. Stresses, probably resulting from differential compaction between the rigid sandstones and the weak shales and claystones, may have induced movement to cause the slickensides.

\section{COAL MINING}

Underground coal mining began in the Somerset district in 1901, when the Utah Coal Mining Co. opened a mine on a 20 -foot-thick seam of bituminous coal (Denman, 1903, p. 93). After the completion of the Denver and Rio Grande Railroad from Delta to Somerset in 1902 (Beebe and Clegg, 1962, p. 374), the mine was shipping about 1,000 tons of coal per day (Lee, 1912, p. 12, 106). All mining in the district has been done by room-and-pillar methods, in which openings (slopes) are driven down the dip of the coal beds. Multiple entries are driven nearly parallel to the strike of the coal beds at intervals of about 500 feet, so that the coal is divided into large blocks several thousand feet long and 500 feet wide (fig. 4). These large blocks then are divided into areas of small, nearly square pillars, most of which are 50 to 60 feet on a side, by driving rooms up the dip of the coal seams from the multiple entries, and by driving small crosscuts between rooms. The rooms are later used as working areas from which the pillars are extracted. During final or "retreat" phases of mining as much of each pillar as possible is removed and the roof is allowed to collapse completely. This collapse eliminates accumulation of abutment stress in nearby working areas; if the roof over large minedout areas does not collapse, large amounts of stress will be concentrated in nearby areas (abutment zones). An attempt formerly was made to keep the pillar lines in the $\mathrm{C}$ bed, along which pillars were being removed, slightly ahead of pillar lines in the B bed below, so that roof-control problems in the $B$ bed could be minimized. The need for such coordinated work no longer exists because mining ceased in the $\mathrm{C}$ bed as a result of large sandstone-filled channels in the coal and of hazards from weak roofs, bumps, and many pots.

Most of the mining in the Somerset mine is now done by continuous-miner machines. Methods formerly used in the district included undercutting the solid coal with hand picks or cutting machines, then blasting or wedging it down (Lee, 1912, p. 94-110). Coal in the Bowie (Juanita) mine which adjoins the Somerset mine to the west (figs. 3, 4), formerly was blocked out by using prominent vertical joints trending $\mathrm{N} .70^{\circ} \mathrm{E}$. as the face. During mining the coal then "snaps from the face with considerable force in some places," according to Lee (1912, p. 104), probably because it was under natural stress and was failing by small bumps.

\section{SEISMIC WORK IN THE SOMERSET DISTRICT}

Seismic activity in the Somerset district was studied from August 30 through September 16, 1969, although continuous recording extended only from September 3 through September 16. The instrumentation system used at Somerset (fig. 6) was similar to one used to study earth tremors in Utah coal mining areas (Osterwald and others, 1971). Most of the system will not be described again in this report, but modifications in instruments and procedures will be described where pertinent. 


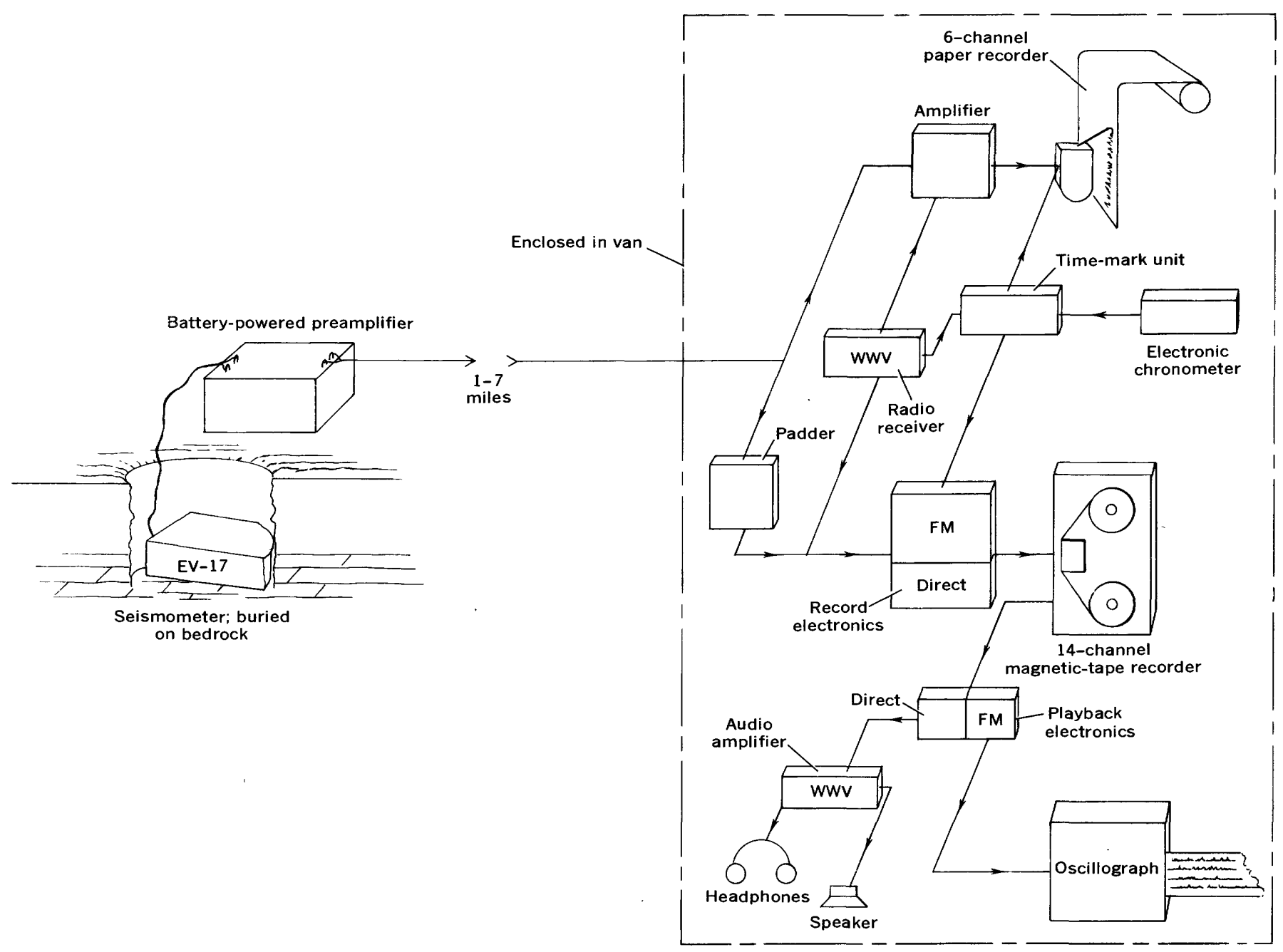

Figure 6. - Block diagram of field instrumentation system used in Somerset mining district.

The instrument van containing the recording equipment and the supporting camp were located in Condemn It Park (fig. 3). Seven vertical component seismometers, sealed in plastic sacks and buried, were arranged in a triangle having sides of about 4 , 5 , and 8 miles. We had considerable trouble placing the seismometers on bedrock because of the heavy surficial cover. The seismometer at station $\mathrm{A}$, in Poison Park about 2 miles north-northwest of Condemn It Park (fig. 3), was on a large landslide mass in the Wasatch Formation. Three EV-17 seismometers were located along a county road in Hubbard Creek canyon southwest of Condemn It Park, and three others were placed along a pack trail extending southeast from Condemn It Park to Thousand Acre Flats (fig. 3). A vertical component Willmore seismometer was installed at station $\mathbf{E}$ (fig. 3 ) on the north slope of Pilot Knob, about 21/2 miles southeast of Condemn It Park. The size and configuration of the array was necessary to give sufficient length and breadth that seismic waves reflected or refracted from deep layers could be detected. The triangular array thus enclosed most of the Somerset mine area.

Signals from all the seismometers were boosted by battery-powered transistorized preamplifiers similar to those used in Utah (Osterwald and others, 1971). Circuitry was added to some of the preamplifiers so that the normal voltage gain of 7,500 could be lowered easily and rapidly to 0.5 at station $\mathrm{B}$, to 2.5 at station $C$, and to 50 at station $F$ (fig. 3) simply by moving the input plugs to different sockets. This was done so that the seismic waves from the nuclear explosion could be recorded properly by selected stations in the network and so that the remaining stations could still retain the capability of recording small earth tremors before and after the explosion. The locations for variable-gain preamplifiers were selected so that the direct seismic energy entering the mine could be compared with that coming out. Frequency response of the preamplifiers is shown in 


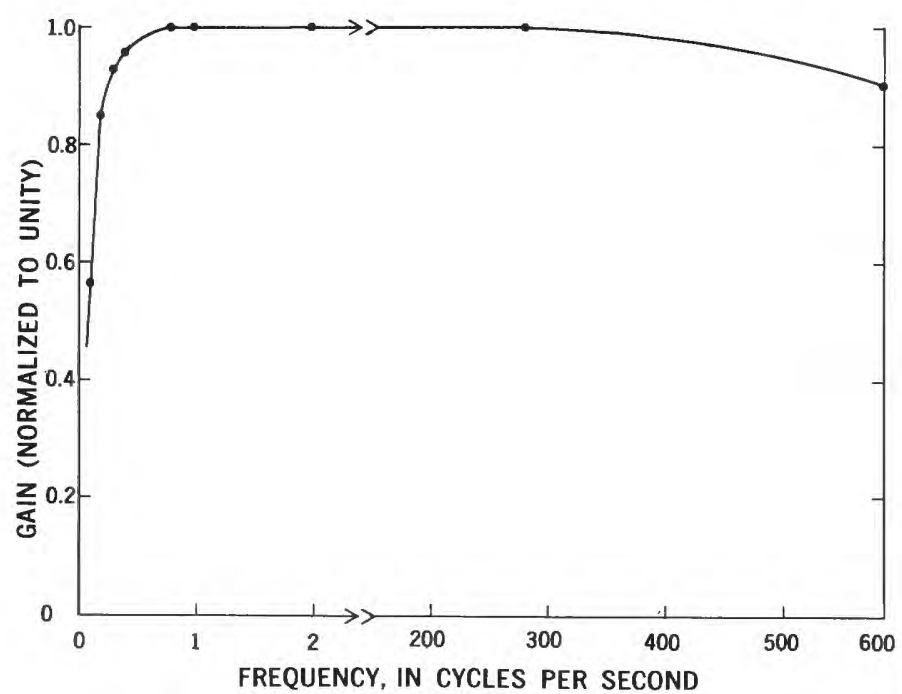

Figure 7. - Frequency response of preamplifier.

figure 7. Signals from the preamplifiers were transmitted to the recording van by military-surplus twisted-pair telephone wire (assault wire). The preamplifiers were powered by nickel-cadmium 15-volt battery packs.

Oscillatory signals were emitted from the preamplifiers during some very heavy rains (fig. 26, trace E). These oscillations probably resulted from electrical ground paths created by water leaking into seismometer cases (although they were sealed in plastic sacks and buried). Other ground paths resulted from water leaking into splices in the signal wires and from spots along the wires where sheep had eaten the insulation.

Signals were split inside the recording van, so that paper and magnetic-tape records were obtained simultaneously (Osterwald and others, 1971) for six of the seismometers. Seismometer G (fig. 3) recorded only on magnetic tape. The various components in the instrument van were arranged as shown in figure 8 . The tape-recording system was changed, however, from our earlier system. Time signals from National Bureau of Standards radio station WWV were recorded with a direct-record system; all other channels were recorded on an FM-record system.

Frequency responses of the storage (tape) and real-time (paper) recording systems are shown in figure 9 . The storage system consists of the seismometers, preamplifiers, tape recorder, and light-beam oscillograph; the real-time system consists of the

FIGURE 9. - Frequency responses of the two recording systems. Curves were derived by experimentation with the systems before they were used in the field monitoring. $A$, FM magnetic tape recorder (storage system). $B$, Paper recorder (real-time system).

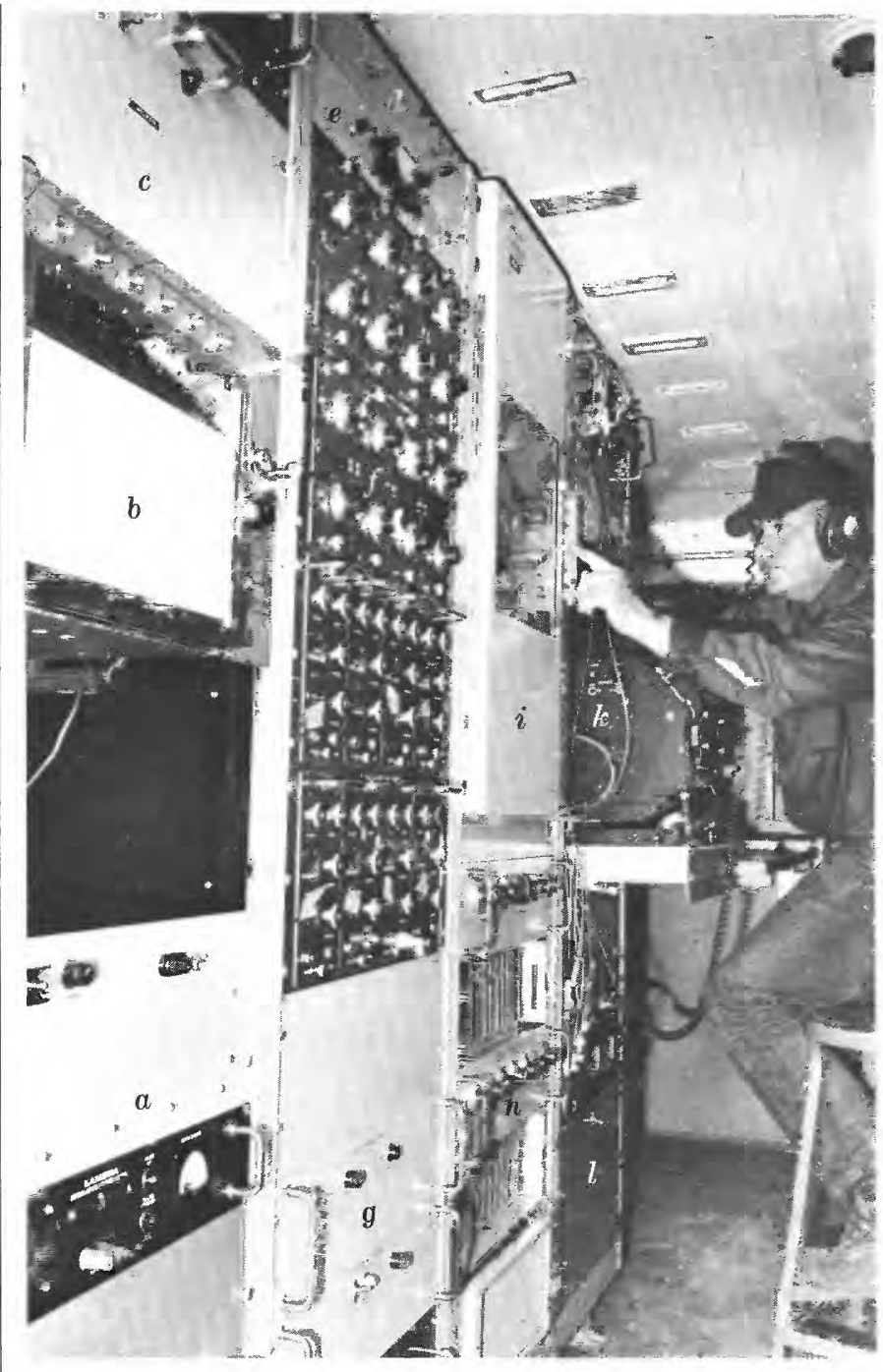

FIGURE 8. - Arrangement of field instrumentation in van. $a$, power supplies; $b, 6$-channel paper recorder; $c$, padders; $d$, time-mark unit; $e$, WWV radio receiver; $f, F M$ and direct-record electronics; $g$, power supplies; $h$, playback electronics: $i$, magnetic tape recorder; $j$, oscilloscope; $k$, oscillograph; $l$, audio amplifier for WWV. Electronic chronometer not shown.

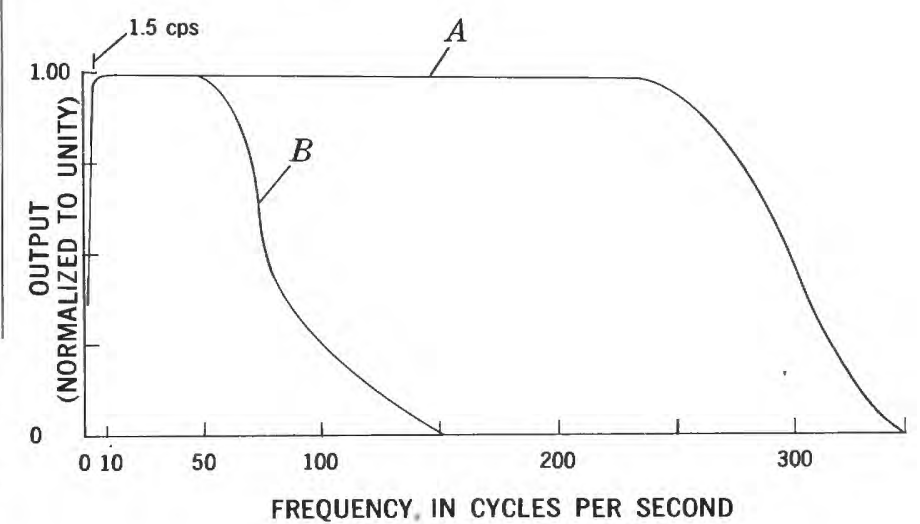




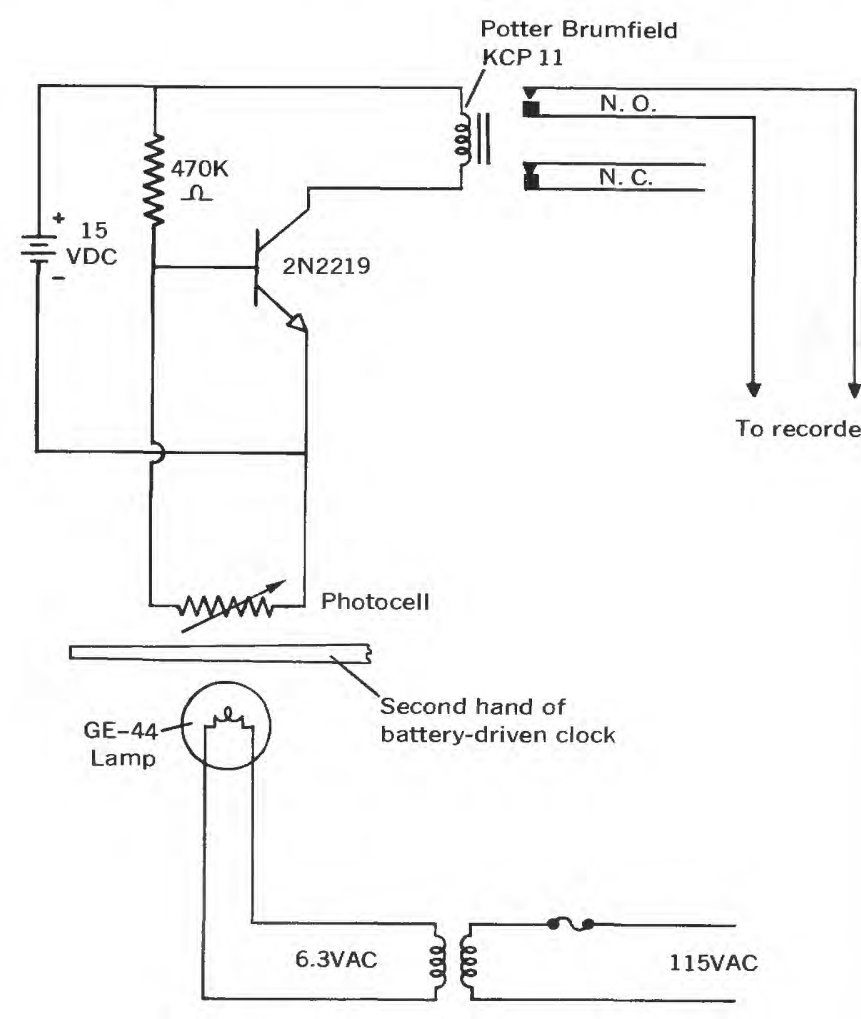

FIGURE 10. - Schematic diagram of photocell-activated chronograph circuit.

seismometers, preamplifiers, pen-drive amplifiers, and electric-writing recorder. By using the storage system, tremors could be replayed on an extended (faster) time base; as a result, a high degree of resolution was obtained in determining arrival times of tremors. The real-time system served as a guide in recovering specific events from the storage system, because both systems were synchronized with National Bureau of Standards radio station WWV in Fort Collins. Time marks were placed on the paper records every minute by a chronograph consisting of a battery-powered clock regulated by tuning fork. A small vane on the second hand of the clock interrupted a light beam focused on a photocell controlling a relay which, when energized, closed a circuit to mark the record (fig. 10).

The recording equipment ran on 60 -cycle 115 -volt single-phase electric power, provided by a 15-kilovolt-ampere gasoline-powered generator unit mounted on a trailer, which also supplied power for the supporting camp. Voltage was maintained automatically; frequency was manually adjusted to 60 cycles by the throttle and was maintained between 59 and 61 cycles by a governor control on the throttle. Occasional governor malfunctions caused us to manually readjust the automatic voltage controls.

Recording equipment was operated 24 hours a day during most of the monitoring period, except for brief periods when the electric-power generator was shut down for servicing. The instrument van was occupied 24 hours a day, and the operation of the instruments, the output voltage, and the frequency of the generator unit were checked every 4 hours. Recording time was about 95 percent of the total elapsed time (fig. 11). We had considerable difficulty with the electronic equipment because of erratic electrical ground paths caused by excessive rainfall which intermittently grounded the generator trailer and instrument van, as well as the signal wires. Thousands of sheep were grazing in the district at the time; they caused innumerable breaks, shorts, and grounds in the signal wires; as a result, various seismometers were not recording part of the time.

Each seismometer installation was calibrated with its corresponding recording channel by injecting a 10-cps (cycles per second) signal from an oscillator into the input of the battery-powered preamplifier. The amplitude of the input signal was sufficient to obtain a 5-volt peak-to-peak signal at the output of

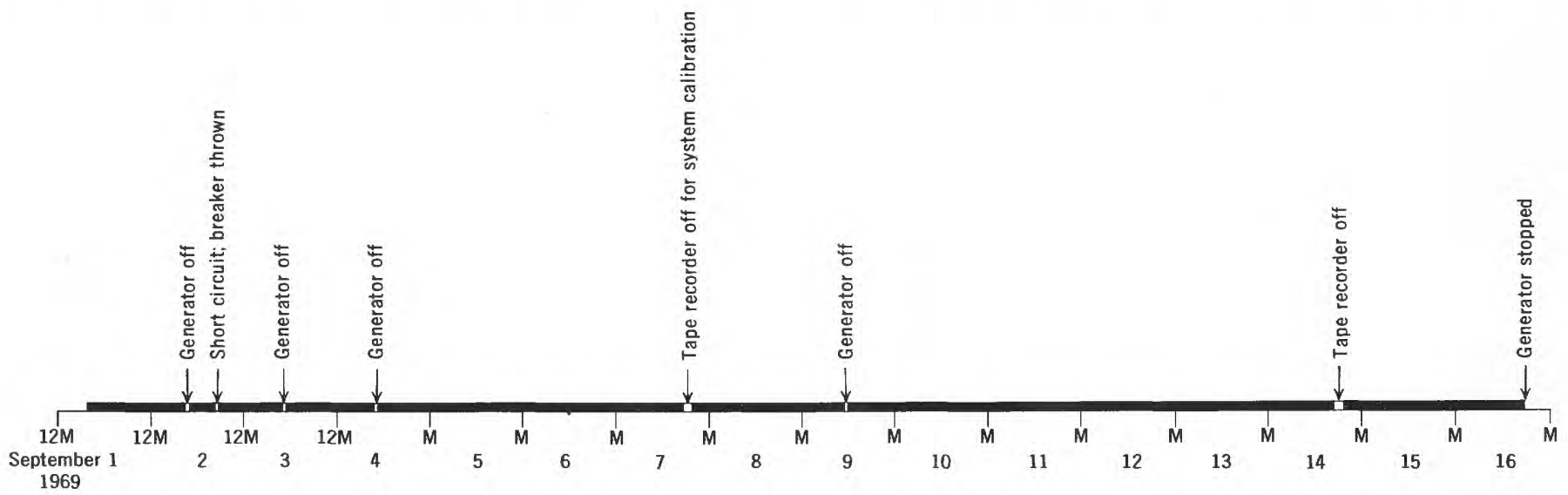

FIGURE 11. - Graph showing total elapsed time of the monitoring period and actual recording time. M, midnight. 
the preamplifier, as measured with a battery-powered oscilloscope. After connecting each preamplifier to the signal wires and to the recorders, the amplitude of the calibration signal from each channel, as recorded in the instrument van, was adjusted with variable attenuators to $20-\mathrm{mm}$ (millimeters) peakto-peak on paper records of the real-time system (fig. 12). The calibration signals also were recorded on magnetic tape in the storage system, and the output of the playback electronics units (figs. 6, 8) was adjusted to yield an amplitude of $25 \mathrm{~mm}$ on the light-beam oscillograph. Both systems were calibrated similarly before the nuclear explosion. During all calibrations the output and frequency response of each seismometer were assumed to correspond to manufacturer's specifications (fig. 13). Frequency response of the storage system was determined by the seismometers on the low-frequency end and by the tape recorder on the high-frequency end.

The recording procedure was similar to that described previously (Osterwald and others, 1971). Arrival times of tremors were indexed on the paper records; individual tremors were located later on the magnetic tape by listening to the voice and International Morse code time announcements from WWV. Tape records of the tremors then were played back at a fast-time base on the light-beam oscillograph (fig. 8), which used a direct-writing light-sensitive paper that required no liquid processing. Timing lines were placed photographically on the paper every 0.01 second and 0.1 second; millisecond timing thus could be interpolated when necessary. Ground velocity of recorded waves was obtained by comparing measured deflections on the records with the deflections from the calibration signals and with the manufacturer's specifications for the seismometers (fig. 13).

\section{SEISMIC INTERPRETATION}

Hypocenters of tremors were located in the field by measuring on the oscillograms the times of arrival of the first seismic waves detected by each seismometer and of the next clearly defined wave groups. A graph then was constructed for each tremor in which first-arrival times at each seismometer were plotted on the horizontal axis and the difference in arrival times between the first waves and the next clearly

Figure 12. - Calibration of station D in real-time (paper) recording system, obtained by injecting a 10-cps 5-volt peak-to-peak signal into the signal line at station $\mathrm{D}$ with a battery-powered oscillator. The variable attenuator in the instrumentation van was then adjusted to get a $20-\mathrm{mm}$ signal on the real-time (paper) recorder, and the galvanometer driver amplifiers were adjusted to give a $25-\mathrm{mm}$ signal amplitude on the oscillograph. defined wave groups were plotted on the vertical axis. On the assumption that both wave groups were generated simultaneously at a point source, a line was drawn connecting corresponding points plotted for different seismometers which, when extended to the

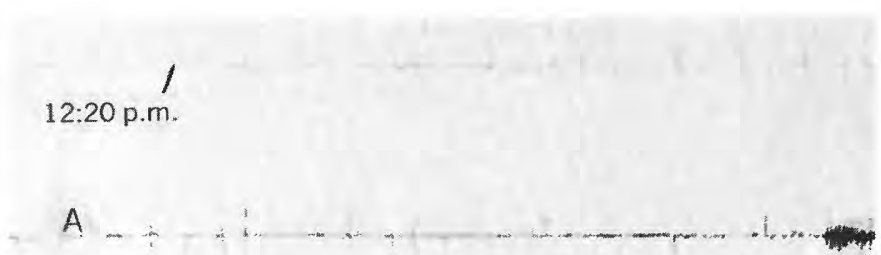

B

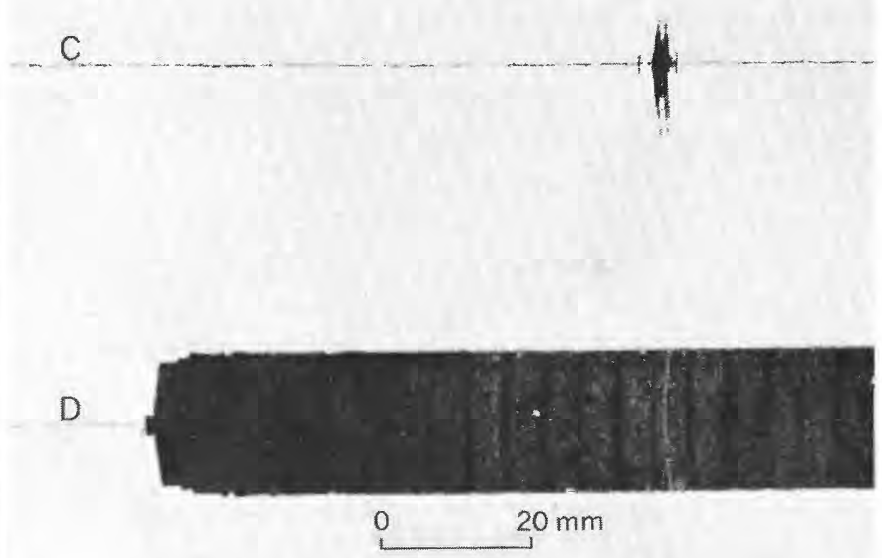

E 


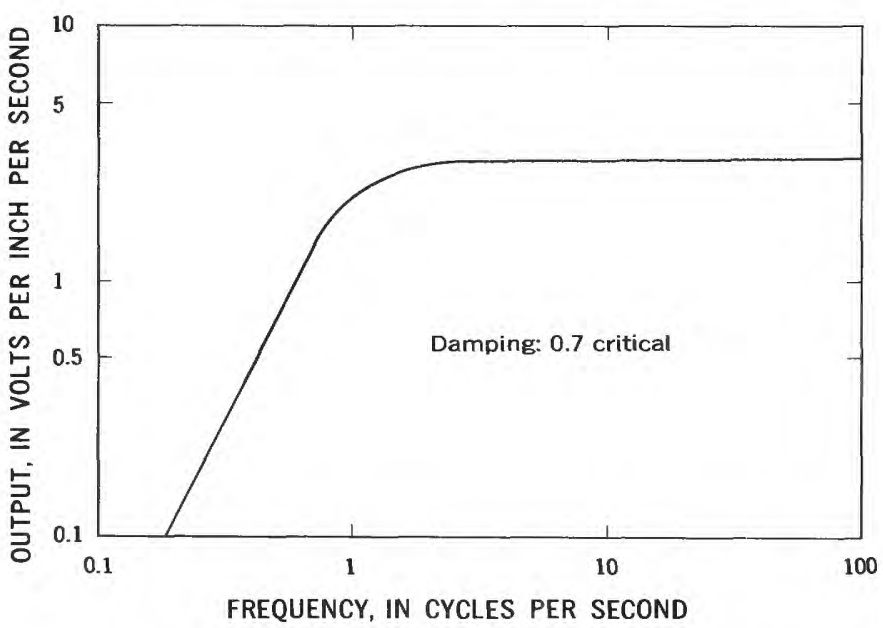

Figure 13. - Frequency response of the EV-17 seismometer, manufacturer's specifications.

horizontal axis, yielded an approximate origin time for each tremor. Traveltimes of the waves to each seismometer were determined by subtracting the arrival time of the first wave (compressional) at each seismometer from the graphically determined origin time.

A protractor specially designed for geologic conditions in the Sunnyside district of Utah was used to determine the hypocenter (map position and focal depth) of each tremor source (Osterwald and others, 1971). Geologic conditions in the Somerset district are sufficiently similar to those at Sunnyside to permit use of the protractor in both places. Use of the protractor to determine hypocenters in the Somerset district was very successful, because intersections from six stations sometimes matched to within 0.01 second on the traveltime curves. Within the district, hypocenters of tremors large enough to be measured on the seismograms probably were located within 1,000 feet of their true positions. Focal depths of tremors, for which no refracted waves were recorded, may be in error by a few thousand feet.

Magnitudes of recorded tremors were estimated by measuring the maximum amplitude of compressional waves on the oscillograms and the paper records. The amplitudes then were compared with the amplitudes of paper records from the fixed seismograph station at the Somerset mine; magnitudes from the fixed station were determined by comparison with records of earthquakes of known magnitude. Magnitudes were further checked by dividing the oscillogram-trace amplitude by 2 and comparing the result with distance-versus-magnitude curves drawn for tremors in the Sunnyside, Utah, district which are detected and recorded by similar equipment. Tremors recorded in the Somerset district varied up to 2.7 in estimated magnitude. Compressional-wave or body-wave magnitudes $(m)$ such as we used are related to Richter magnitude $(M)$ (Richter, 1958, p. 340-345, 348-349) according to the following equation (Davies, 1968, p. 25) :

$$
m=2.5+0.63 M \text {. }
$$

Analyses of seismograms from tremors whose waves were refracted from deep stratigraphic levels suggest that an important high-velocity layer exists about 6,500 feet below the Somerset district. This layer is about 2,000 feet nearer the surface than an important high-velocity layer in the Sunnyside district (Tibbetts and others, 1966, p. D134) ; refracted waves from tremors whose map position was determined accurately arrived at seismometers about 0.1 second sooner than similar waves in the Sunnyside district. The high-velocity layer at Somerset is of unknown composition but may be an igneous sill because no limestones or other high-velocity rocks are known at that depth from drill records.

Between September 3 and September 16, 1969, we operated the mobile recording equipment almost continuously in the Somerset district (fig. 11). During this time 38 tremors were recorded by the mobile equipment; 13 of these occurred within the district and were detected by several instruments, and so hypocenters could be determined (fig. 4). During this same period the fixed station (ELK, figs. 3, 4) at the Somerset mine recorded 517 tremors. Most tremors recorded by the mobile equipment were of local origin, but two resulted from nuclear explosions, and three were from earthquakes that originated outside the district. One of the nuclear explosions was near Grand Valley (project RULISON) (figs. 1, 2), and the other was in Nevada. At least two of the earthquakes probably occurred near the site of the Rulison explosion, because their wave trains were similar to those generated by the actual explosion. Several sonic booms from aircraft were also recorded.

Three types of earth tremors that originated within the Somerset district were recorded by the mobile equipment. The first type consisted of short wave trains that had moderately high amplitudes (fig. 14); these tremors were similar to ones recorded previously in the Hiawatha and Sunnyside districts, Utah (Osterwald and others, 1971), that we inferred to have originated near the recording sites and to have shallow foci. The second type of tremor consisted of wave trains that were longer and were of higher amplitude and lower frequency than the first type (figs. 14, 15). Several wave-group arrivals can be seen in the compressional part of the 
seismograms, and waves in the trains have repeated amplitude peaks, probably resulting from reflections or refractions from deep rock layers. This type of tremor originated farther from the seismometers and perhaps from deeper sources than the first type, because the various wave groups, which travel at different velocities, are separated more than those of the first type. The third type of tremor resulted in seismograms showing wave trains of about the same duration and frequency as the second type but had high-amplitude waves that were preceded by low but increasingly large compressional waves (fig. 16, trace A) ; this type wave produced seismograms that roughily resembled those produced by sonic booms from jet aircraft as recorded by the fixed station (fig. 19). Records from the mobile system, however, which were observed to have been caused by sonic booms, have a much shorter wave train. The origin of the third type of tremor is not known.

A fourth type of tremor generated wave trains of about the same duration and frequency as the second type, but late-arriving wave groups had rapidly decreasing amplitudes. This type of tremor probably originated at deeper levels than the second type but also may have resulted from a different source mechanism.

During the recording period the fixed station at the Somerset mine recorded some of the same types of tremors as the mobile equipment. Seismograms from the fixed station, however, differ in appearance from those of the network because the recorder at the fixed station is operated at a faster speed. Tremors of the first and second types (p. 14), when recorded at the fixed station (figs. 17, 18), showed the wave characteristics, envelope, and frequency much more clearly than when recorded by the mobile equipment.

The fixed station also recorded many sonic booms from jet aircraft; these are easily recognized by their long wave train, low-amplitude first-arriving waves, a group of large-amplitude waves arriving next, and long, low-amplitude late waves (fig. 19). An additional type of tremor recorded by the fixed

Figure 14. - Seismogram of first type of tremor, recorded by real-time system in the mobile network at 10:40 p.m. m.d.t. on September 10, 1969 (0440 G.m.t. Sept. 11). Tremor probably had a shallow focus within the Somerset district and consisted of a short wave train. Letters designate seismometers shown in figure 3. Seismometer A was out of service. Time progresses from left to right; 1-minute time intervals shown by chronograph ticks at top. Hypocenter is No. 4 in figures 3 and 4; magnitude is 1.9. See also figure 17 . station but not by the mobile equipment, consisted of long low-amplitude wave trains that showed highfrequency compressional phases and low-frequency late phases (fig. 20); the origin of this type of
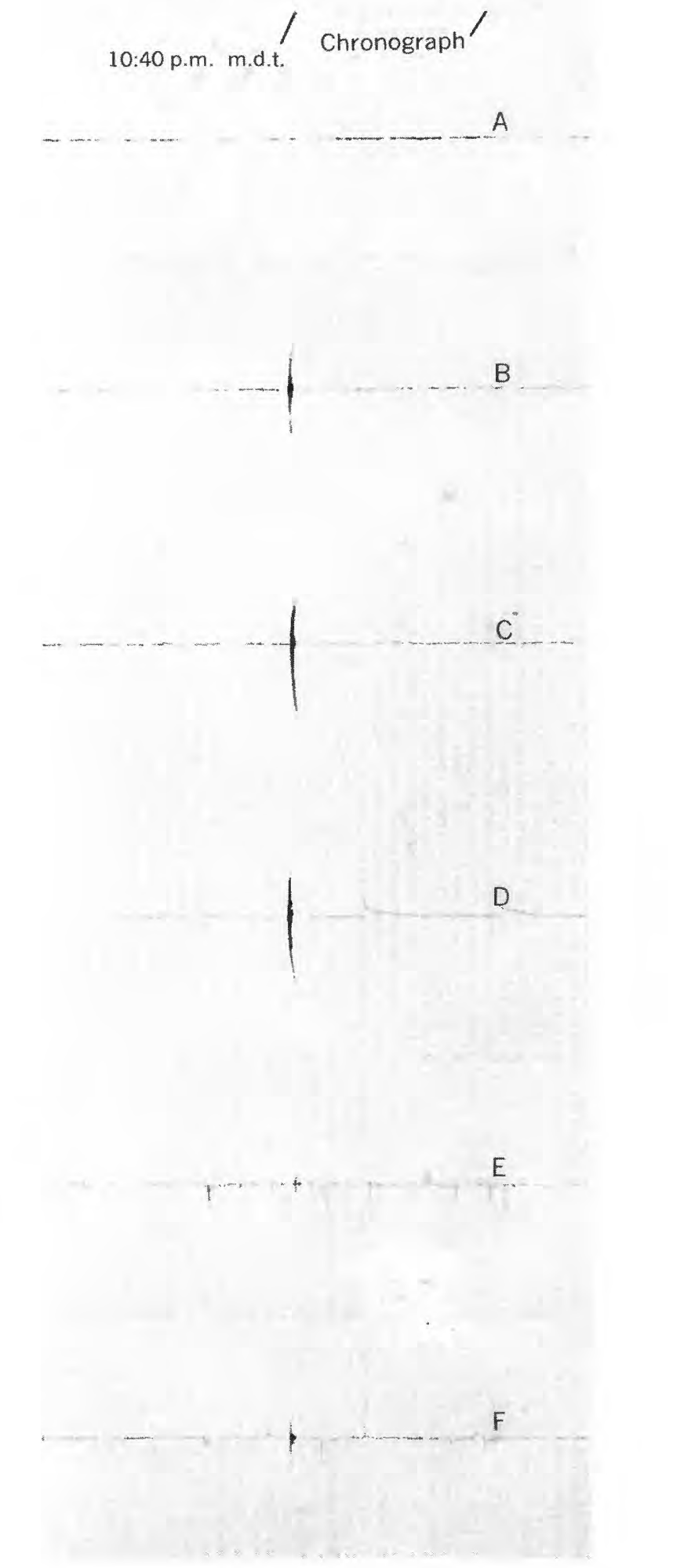

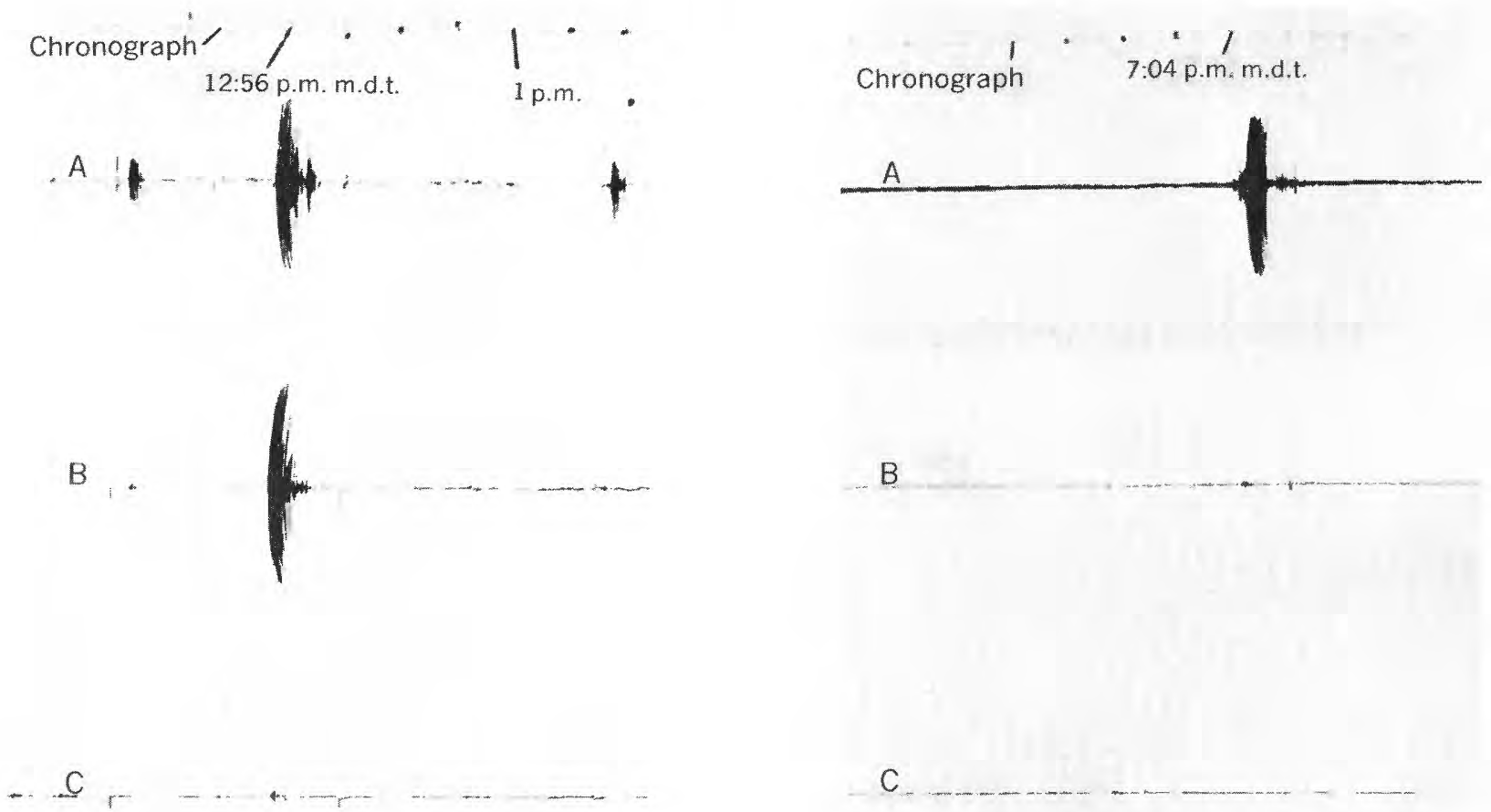

D
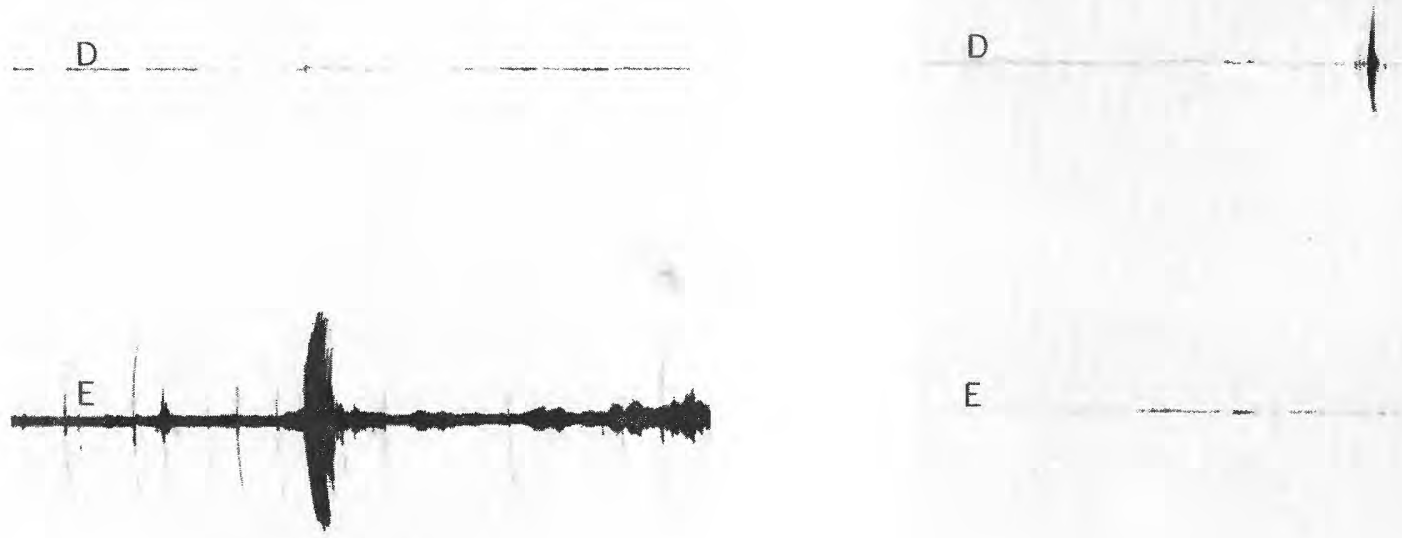

E

B

C.
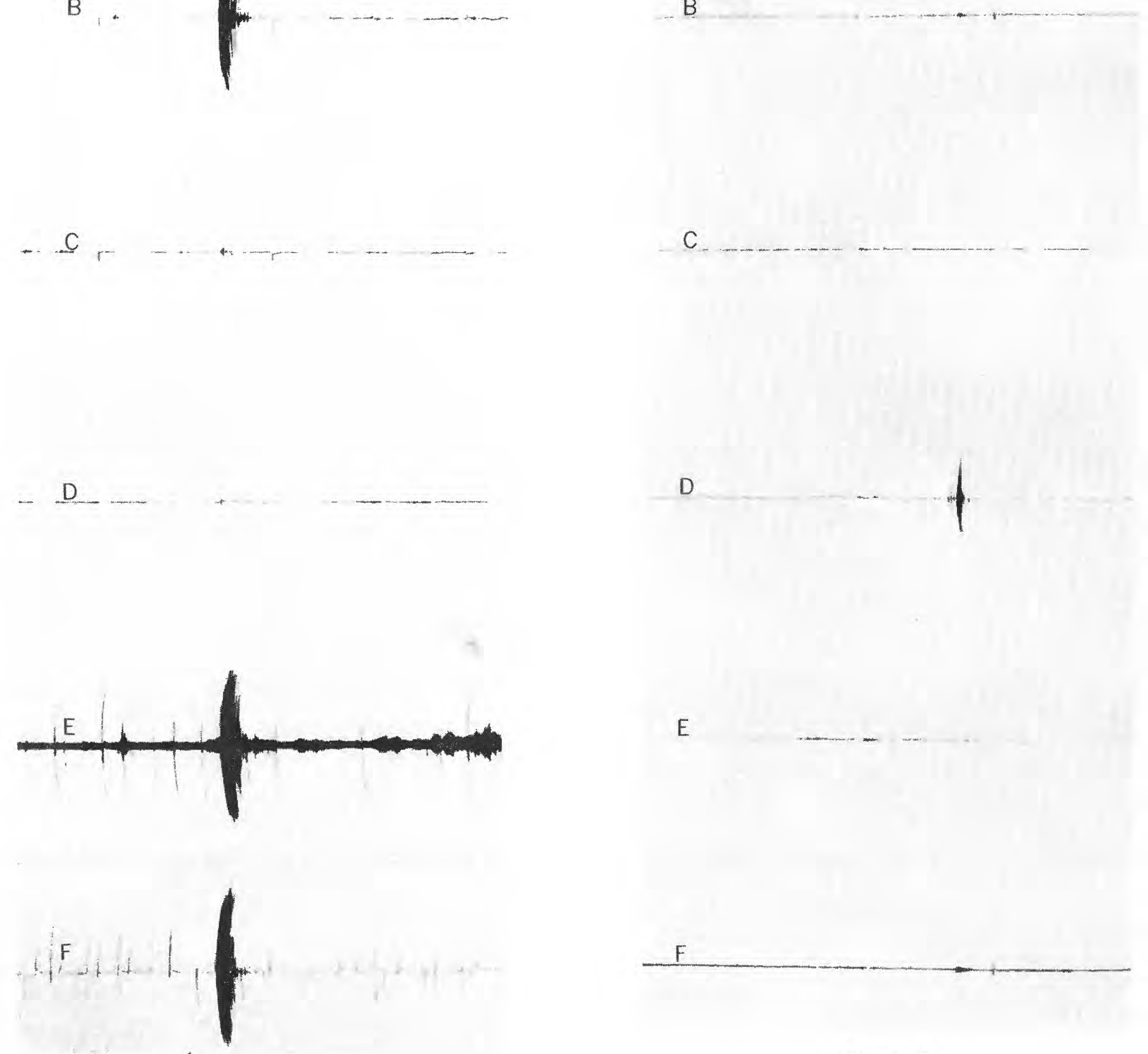

FIgURE 16.

Figure 15. 
Figure 15. - Seismogram of second type of tremor, recorded by the real-time system in the mobile network at $12: 56$ p.m. m.d.t. (1856 G.m.t.) on September 16, 1969. High amplitude and long wave train with successive peaks probably indicate deeper source than tremor in figure 14; waves refracted from successively deeper strata. Letters designate seismometers shown in figure 3. Time progresses from left to right; 1-minute time intervals shown by chronograph ticks at top. Hypocenter is No. 11 of figures 3 and 4 ; magnitude is about 2.7. See also figure 18.

Figure 16. - Seismogram of third type of tremor recorded by real-time system in the mobile network at 7:04 p.m. m.d.t. (0104 G.m.t.) on September 3, 1969. Letters designate seismometers shown in figure 3. Seismometers $\mathrm{C}$ and $\mathrm{E}$ were out of service. Time progresses from left to right; 1-minute time intervals shown by chronograph ticks at top.

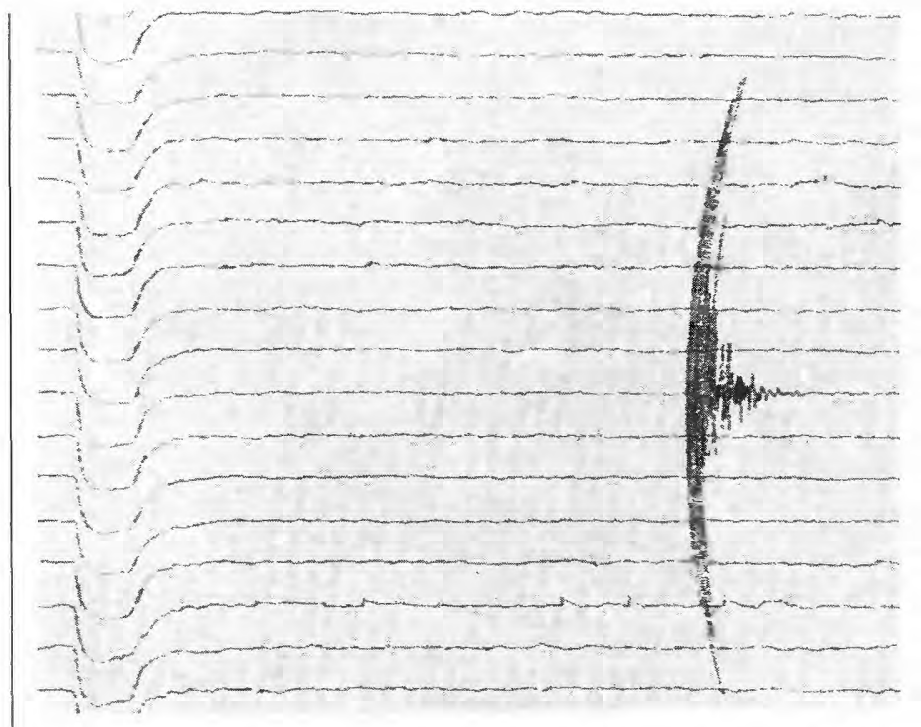

FigURE 17. - Seismogram of first type of tremor, recorded by the fixed station at 4:47:40 a.m. m.d.t. (114740 G.m.t.) on September 3, 1969. Consists of high amplitude and short wave train. Time progresses from left to right. Chronograph break on line to left of tremor is 4:47 a.m.; break is of 3 seconds' duration. Tremor was too small for hypocenter and magnitude to be determined.

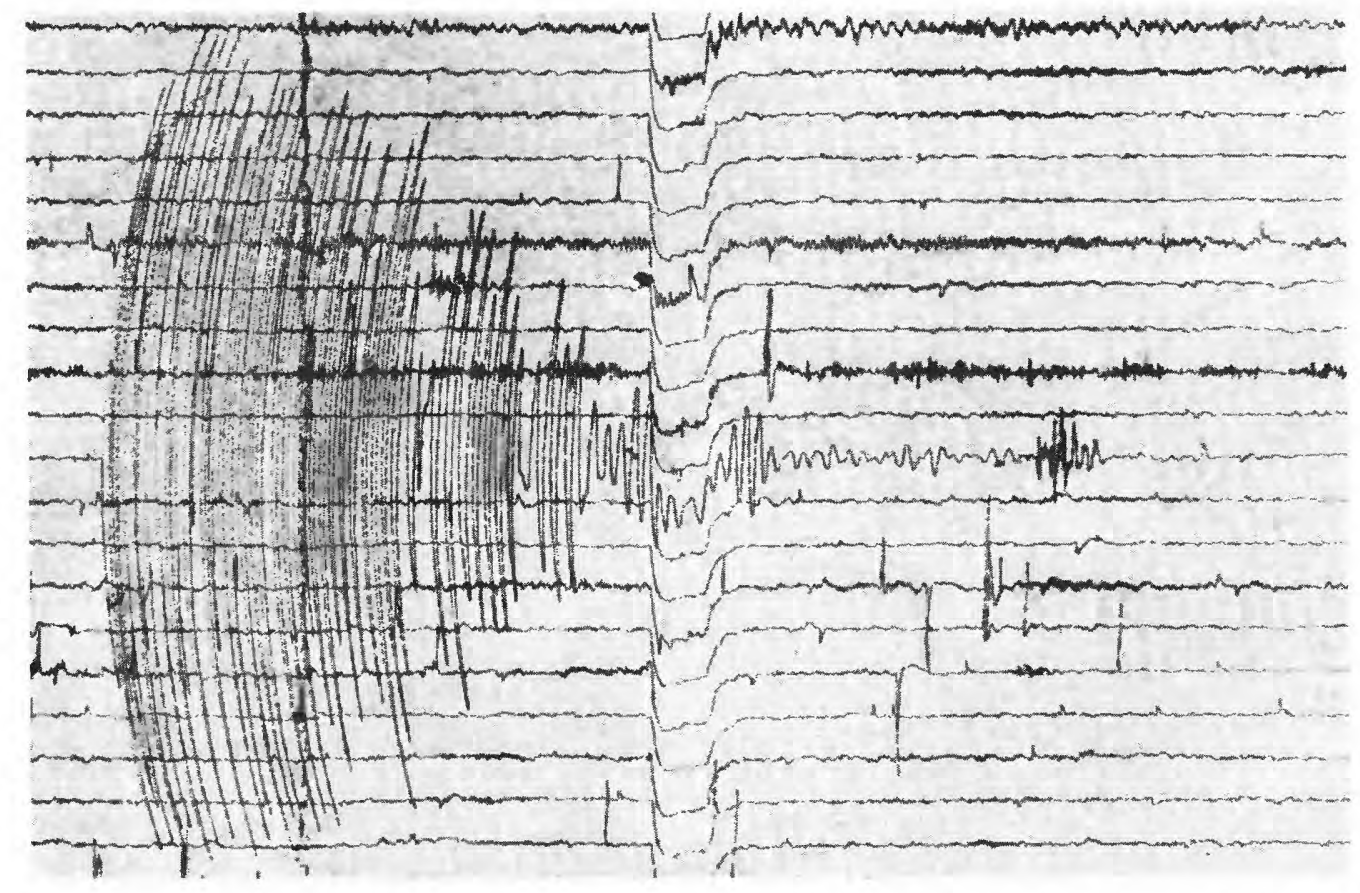

FIGURE 18. - Seismogram of second type of tremor, recorded by the fixed station at about 12:55 a.m. m.d.t. (1855 G.m.t.) on September 16, 1969. Consists of high amplitude, long wave train, high-frequency compressional waves, and wave envelope with several peaks. Time progresses from left to right; 1-minute intervals shown by successive chronograph breaks. Hypocenter is No. 11 of figures 3 and 4; magnitude about 2.5. 


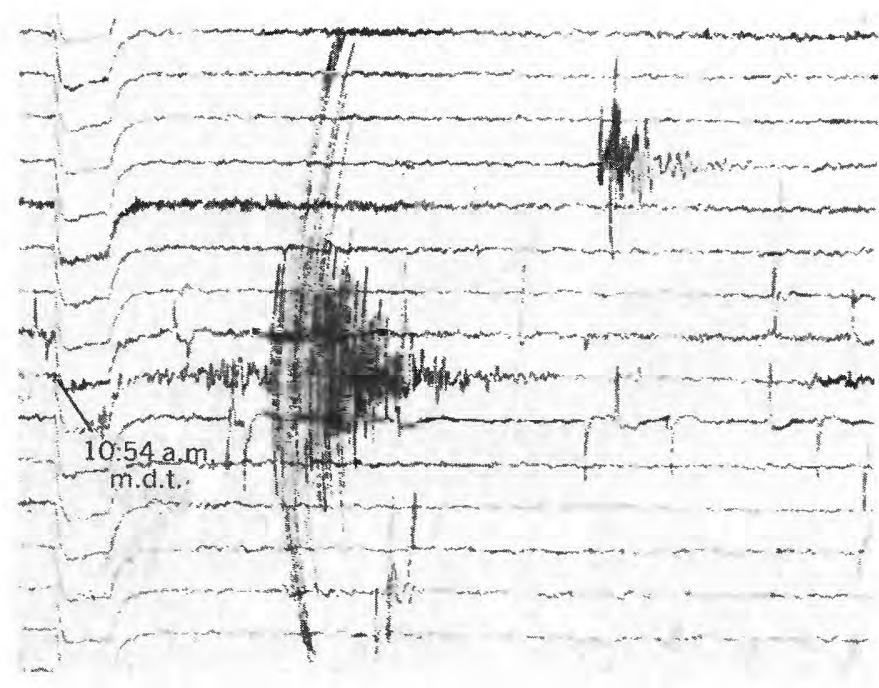

FIGURE 19. - Seismogram of sonic boom from jet aircraft, recorded by the fixed station at 10:54 a.m. m.d.t. (1854 G.m.t.) on September 16, 1969. Low-amplitude compressional waves precede a high-amplitude but short wave train. 1-minute intervals shown by successive chonographic breaks.

tremor is not known, but the source was probably outside the Somerset district.

Of the 13 tremors whose hypocenters could be determined, 12 were within 1 mile of active mining areas of the Somerset mine (figs. 3, 4). Map positions of six tremors $(2-4,11-13)$ roughly formed a north-northeast-trending line less than half a mile east of Hubbard Creek, adjacent to part of the mine that was being developed actively. This line, perhaps coincidentally, parallels several faults east and west of the Somerset mine. Although no faults were encountered during mining in this area, three clastic dikes were found on trend with this line of tremors (fig. 4). The foci of these tremors were between sea level and 5,000 feet above sea level, or between 1,000 and 6,000 feet below the mine. Two tremors in the line had the highest magnitudes (2.6 and 2.7) of any natural tremors recorded in the district with the mobile equipment. The line of tremors probably resulted from the release and unequal redistribution of stress concentrated near a zone of steep dip in the C coal bed and the clastic dikes, as a result of nearby mining. The zone, probably resulting from compaction around a large sandstone-filled channel, compacted less than adjacent sections of rock and coal. Thus, a discontinuity was formed in which stress concentrated as a result of removal of overburden support by mining. The zone of steep dip in the $\mathrm{C}$ bed (p. 9) also intersects some of the dikes and the line of tremor hypocenters (fig. 4). The line of tremor hypocenters apparently was beneath a zone

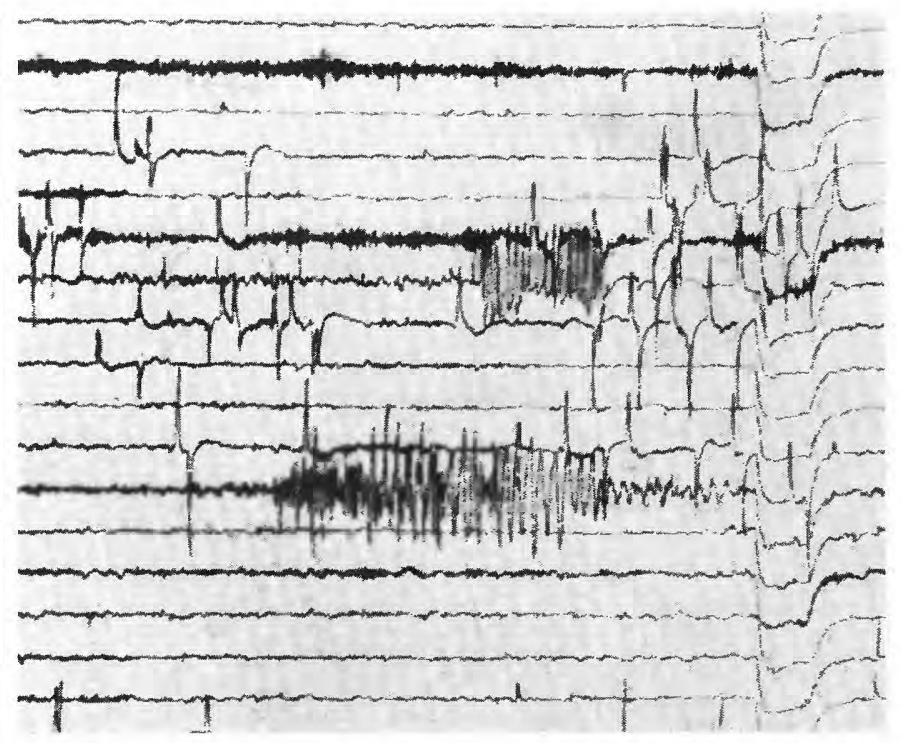

FiguRE 20. - Seismogram, recorded by fixed station at about 10:18:30 p.m. m.d.t. on September 16, 1969 (041830 G.m.t. Sept. 17, 1969). Tremor has long wave train with highfrequency compressional waves and low-frequency late phases. Source probably was outside the Somerset district, hence hypocenter and magnitude could not be determined. Chronograph break at right is about 3 seconds' duration.

of high abutment stress in nearby active mining areas (fig. 3) that resulted from rapid removal of coal. The line of hypocenters may also have resulted in part from redistribution of stresses beneath the east wall of the canyon of Hubbard Creek, where stress from overburden changes rapidly within short distances.

Most other tremors whose hypocenters could be located also occurred within the mining area (figs. $3,4)$ and probably resulted directly from stress redistribution caused by mining. Most of these tremors occurred near areas in the mine from which pillars were being removed. Such tremors apparently increased in abundance after the RULISON explosion, probably as a result of slight increments of energy added to the area by seismic waves from the explosion. Foci of these tremors were $1,000-4,000$ feet below the mine workings (from 2,000 to 5,000 $\mathrm{ft}$ above sea level). The tremor which occurred about 6 miles north of the mine (hypocenter No. 5, fig. 3) probably was a natural earthquake.

The number of tremors recorded each day by the mobile network in the Somerset district varied widely (fig. 21A). The causes of the variations are not known, but the occurrence pattern was somewhat similar to the pattern of tremors per day recorded during the same period in the Sunnyside district, Utah (fig. $21 B$ ), where many tremors were thought to be related to mining (Barnes and others, 1969), 


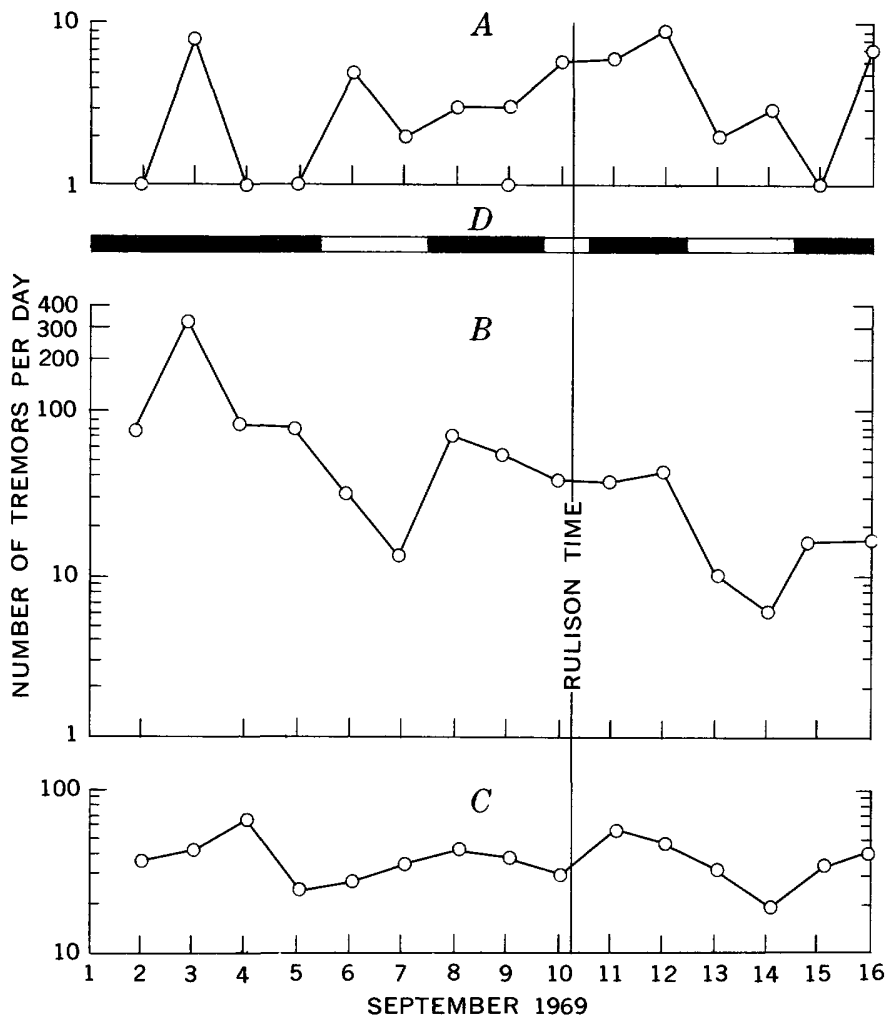

Figure 21. - Semilogarithmic plots of number of tremors per day recorded by: $A$, mobile network in Somerset mining district. Average number of tremors daily: four during mining, three during idle day, standard deviation 4 each. $B$, Fixed station near Sunnyside (Bear Canyon), Utah. $C$, Fixed station at Somerset, Colo. Average number of tremors daily: 41 during mining, 29 during idle day, standard deviations 12 and 5 , respectively. $D$, Times when mining work was being done in Somerset mine (shown by black sections).

although total numbers of tremors at Sunnyside were much greater (fig. $21 B$ ). Some of these variations may have resulted because the signal wires connecting the seismometer stations closest to the Somerset mine, which were the longest wires in the network, were broken more frequently than the shorter wires. The pattern of tremor occurrence recorded by the mobile network (fig. $21 A$ ), therefore, is different from the pattern recorded by the fixed station, which operated continuously (fig. $21 C$ ). Little relation is apparent between the occurrence pattern of all the tremors recorded by the mobile network and by the fixed station (fig. $21 \mathrm{C}$ ). The rates of occurrence of all the tremors recorded by the mobile network also bear little obvious relationship to times of mining activity in the Somerset mine (fig. $21 D$ ), although such relationships between mining and occurrence patterns of tremors were reported for the Sunnyside and Hiawatha districts in Utah during monitoring experiments similar to the one at Somerset (Oster-

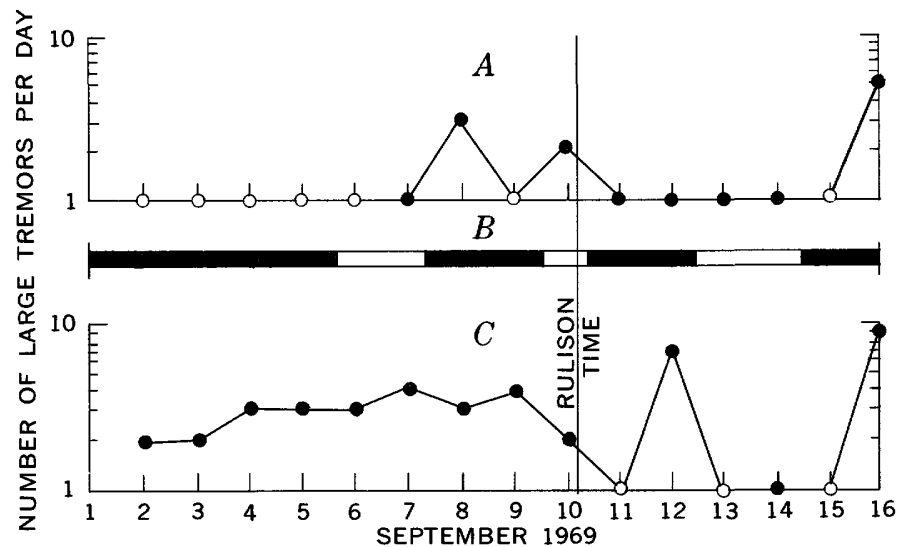

FIgURE 22. - Semilogarithmic plots of number of large tremors per day. $A$, Natural tremors that were large enough to determine hypocenters, mobile network. $B$, Times when no mining work was being done (shown by black sections). $C$, Fixed station, showing number of tremors whose estimated magnitudes were greater than 1.0. Open circles indicate days of recording when no tremor occurred. Days marked at 12:00 noon.

wald and others, 1971). The average daily rate of occurrence of all tremors recorded by the fixed station during the monitoring period, however, was greater on days when mining was done than on days when no mining was done (fig. $21 A, C, D$ ).

No apparent correlation was found between times of active mining in the Somerset mine during the monitoring period and the occurrences of tremors that were large enough to be detected by three or more stations in the mobile network (fig. $22 A, B$ ). The occurrence pattern of such large tremors recorded by the mobile network (fig. 22A) generally is not similar to the occurrence pattern of large tremors recorded by the fixed station at the Somerset mine (fig. $22 C$ ), which also shows no relationship to times of mining activity (fig. 22B). Small sections of the curves do show some similarities, as should be expected because the seismometers were measuring adjoining areas, but the entire network received signals from a much larger area than did the Somerset mine seismograph.

\section{EFFECTS OF NUCLEAR EXPLOSIONS}

A 40-kiloton-equivalent nuclear explosion was detonated 41 miles northwest of the town of Somerset at 3 p.m. m.d.t. (2100 G.m.t.) on September 10, 1969 (Gauss, 1969). Before this explosion, which probably was detonated in the lower coal member of the Mesaverde Formation (U.S. Atomic Energy Comm., 1969, p. 13), considerable local apprehension had arisen that the shock waves would damage various coal mines in the Grand Mesa coal field (Saile, 1969; Denver Post, 1969). We hoped to measure the effects 


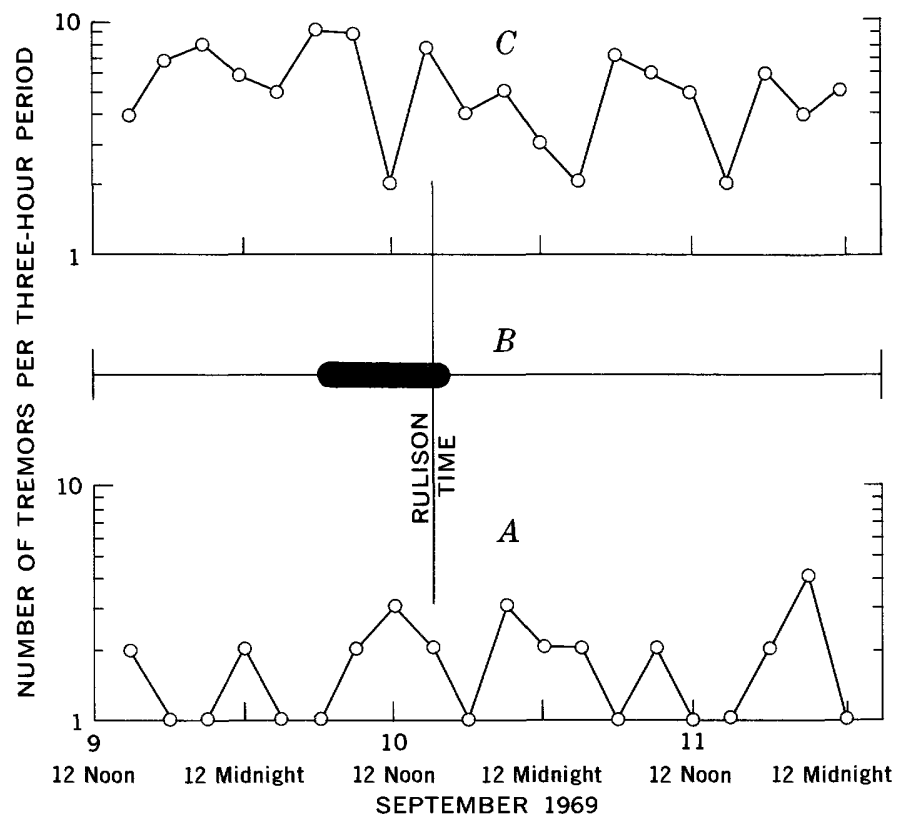

FIgURE 23. - Semilogarithmic plots of seismic activity summed for each 3-hour period from 12 noon, September 9 , 1969 , to 12 midnight, Sept. 11, 1969. $A$, Mobile network. $B$, Times when no mining was done (shown by black section). $C$, Fixed station.

of this explosion around the Somerset mine and to determine whether any change in the seismic activity occurred after the explosion.

The daily occurrence pattern of large tremors recorded by the mobile network and by the fixed station changed after the nuclear explosion at Rulison (fig. 22). Maximum number of large tremors per day increased, and variations in this maximum were greater than before the explosion. No changes, however, were detected in the numbers of tremors per day after the explosion either by the mobile network or by the fixed station (fig. 21).

The total number of tremors recorded by the network and the number recorded by the fixed station were summed separately for each 3-hour period from 12 noon (m.d.t.) September 9 to 12 midnight September 11, so that the activity could be analyzed for shorter periods of time (fig. 23). We detected no significant changes in occurrence pattern recorded by the mobile network before or after the nuclear explosion and found no change in pattern during the time that the Somerset mine was worked after the explosion (fig. 23). We could not analyze the occurrence pattern of large tremors for the shorter periods of time, because of the small number of such tremors. We did observe much more variation in the 3-hour occurrence pattern recorded by the fixed station after the nuclear explosion, probably because the seismometer at the fixed station was closer to the mine than the seismometers in the mobile network (fig. $23 \mathrm{C}$ ) and because of the rapid stress changes around the actively mined areas.

The first ground motion from the RULISON explosion was recorded by station $\mathrm{E}$ of the mobile network at $21: 00: 10.6$ G.m.t. on September 10 (fig. $26)$. The amplitude on the record was limited by the maximum electronic output of the preamplifier and is not a true indication of actual ground motion. Station F, which had a lower gain setting than station $\mathrm{E}$, recorded the complete wave envelope (fig. $24)$; the first ground motion was detected by station $\mathrm{F}$ at $21: 00: 11.4$ G.m.t., and maximum ground velocity was recorded 4.8 seconds later. Station $F$ was on about 10 feet of surficial material and therefore was not coupled to bedrock. Consequently, ground motion may have been slightly amplified, and arrival times, slightly delayed.

The peak record deflection produced by the EV-17 seismometer at station $F$ and recorded by the tape system was $28 \mathrm{~mm}$. Using the manufacturer's output specifications of the EV-17 and the system-calibration information, shown by the measured deflection of a 10-cps 5-volt peak-to-peak calibration signal (fig. 25), we calculated the peak ground velocity at station $\mathrm{F}$, as follows:

Given:

Preamplifier gain $=G_{p}=50$,

Record deflection constant $=K_{2}=5 \mathrm{~mm} /$ volt (by calibration),

Seismometer output constant $=K_{1}=1.18$ volts/ $\mathrm{cm} / \mathrm{sec}$ (manufacturer's specs.), and

Record deflection $=D=28 \mathrm{~mm}=2.8 \mathrm{~cm}$,

let: Ground velocity $=V$,

Line voltage into truck $=E_{T}$, and

Seismometer output voltage $=E_{p}$;

then : $E_{p}=V \times K_{1}$, so

$$
\begin{aligned}
K_{1}= & E_{p} / V=1.18 \mathrm{volts} / \mathrm{cm} / \mathrm{sec} \text { (manufac- } \\
& \text { turer's specs.), }
\end{aligned}
$$

and: $D=K_{2} \times E_{T}$, so

$$
K_{2}=D / E_{T}=0.5 \mathrm{~cm} / \text { volt (by calibration, }
$$
fig. 25).

Also: $D=E_{T} \times K_{2}=K_{2} \times E_{p} \times G_{p}=K_{2} \times K_{1} \times V \times G_{p}$, but: $\mathrm{D}=2.8 \mathrm{~cm}$, therefore: $K_{2} \times K_{1} \times V \times G_{p}=2.8 \mathrm{~cm}$.

Solving for $V$, we have: $V=2.8 \mathrm{~cm} / K_{2} \times K_{1} \times G_{p}$; substituting:

$$
\mathrm{V}=2.8 \mathrm{~cm} / 0.5 \mathrm{~cm} / \text { volt } \times 1.18 \frac{\text { volts }}{\mathrm{cm} / \mathrm{sec}} \times 50,
$$

therefore: $V=.095 \mathrm{~cm} / \mathrm{sec}$ (peak ground velocity at station F). 

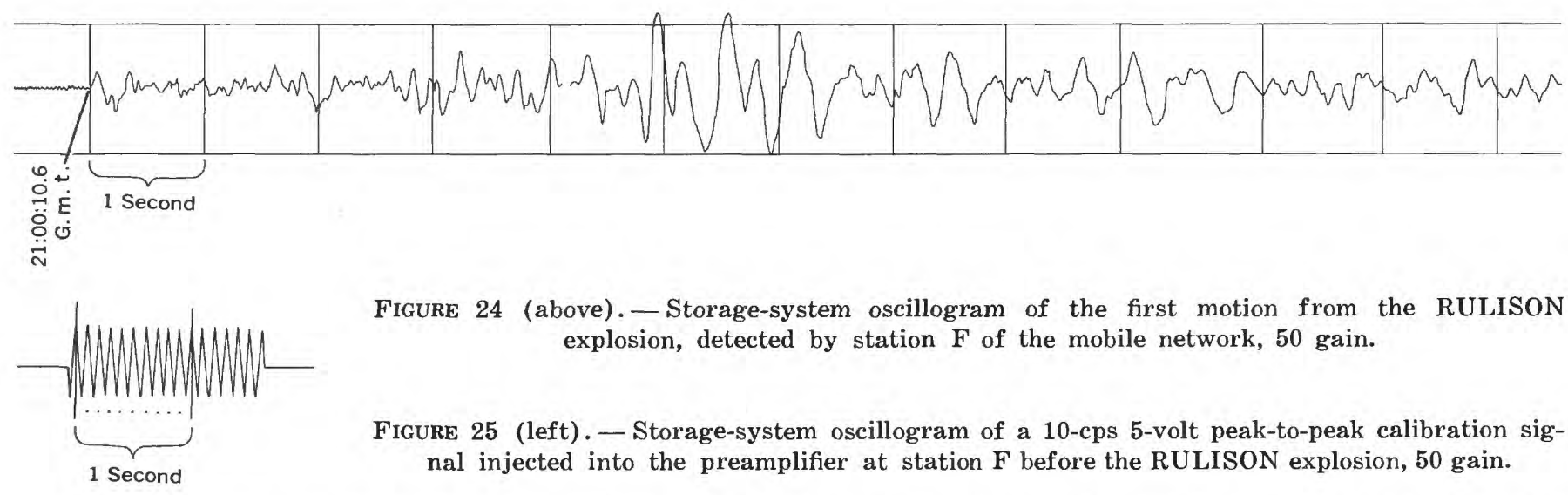

FIGURE 24 (above). - Storage-system oscillogram of the first motion from the RULISON explosion, detected by station $\mathrm{F}$ of the mobile network, 50 gain.

FIgURe 25 (left). - Storage-system oscillogram of a 10-cps 5-volt peak-to-peak calibration signal injected into the preamplifier at station $F$ before the RULISON explosion, 50 gain.

Maximum displacement and acceleration of the recorded shock waves at station $\mathrm{F}$ were calculated by using simple harmonic-motion theory. The maximum wave group was assumed to be sinusoidal with a frequency $(f)$ of 4 cps (fig. 24). Let:

$d=$ peak ground amplitude or maximum vertical ground displacement, $V p=2 \pi f A p=$ peak vertical velocity, $|A p|=2 \pi f V p=$ absolute value of peak vertical acceleration,

$g=972 \mathrm{~cm} / \mathrm{sec}^{2}=$ acceleration of gravity at 8,800 feet above mean sea level, $39^{\circ} \mathrm{N}$. latitude, and $A g=$ number of gravities of acceleration.

Substituting known values in equation 2 , we have:

$$
\begin{aligned}
d=\frac{V p}{2 \pi f} & =\frac{0.095 \mathrm{~cm} / \mathrm{sec}}{(2 \pi)(4 \mathrm{cycles} / \mathrm{sec})} \\
& =3.78 \times 10^{-3} \mathrm{~cm}, \text { or } 37.8 \text { microns. }
\end{aligned}
$$

Substituting known values in equation 3 , we have:

$$
\begin{aligned}
|A p| & =2 \pi(4 \mathrm{cycles} / \mathrm{sec})(0.095 \mathrm{~cm} / \mathrm{sec}) \\
& =2.39 \mathrm{~cm} / \mathrm{sec}^{2}
\end{aligned}
$$

Referencing this to the acceleration of gravity, we have:

$$
\begin{aligned}
A g & =\frac{A p}{g}=\frac{2.39 \mathrm{~cm} / \mathrm{sec}^{2}}{972 \mathrm{~cm} / \mathrm{sec}^{2}} \\
& =2.46 \times 10^{-3} g
\end{aligned}
$$

The paper record of the RULISON explosion shows clearly the response of stations with various gains in the mobile network to the shock waves (fig. 26). The RULISON explosion was not recorded by the fixed station at the Somerset mine because the shock waves were of lesser intensity than we expected and because we had set the preamplifier gain too low to obtain a recording. Stations D, which had a normal gain of 7,500, and $\mathrm{E}$, which had an equivalent preamplifier gain of 30,000 coupled to a Willmore seismometer, produced the largest deflections. Many of the wave envelopes from stations $\mathrm{D}$ and $\mathrm{E}$ were limited by the maximum voltage output from the preamplifiers. Thus, maximum amplitude of the shock waves cannot be determined from the deflections on these records. They can, however, be compared with the records of tremors from local sources (figs. 14, 15, 16) to indicate the relative maximum amplitude and length of wave trains from the explosion. This comparison gives a rough impression of the energy imparted to the Somerset district by the explosion.

Our field observations at different locations within the network and reports of miners and local residents show that the peak deflections measured from the oscillograms, such as shown on fig. 24, were higher than the average ground motion in the district. Ground motion apparently was more intense at higher elevations, where thick surficial cover on the Wasatch Formation (figs. 3,4 ) caused some amplification of the ground motion. It was less intense at lower elevations in the valley of the North Fork of the Gunnison River and its tributary canyons. Considerable ground shaking was observed at station $\mathbf{F}$ (Jerome Hernandez, oral commun., 1969) and by Dunrud at station C, whereas people in the Somerset mine and in Somerset and Paonia reported very little shaking (Donald Chapman, oral commun., 1969). A nickel placed on edge on a haulage rail in the Somerset mine was not disturbed by the seismic wave (Paul Butler, oral commun., 1969). The greater shaking at higher elevations than at low elevations may also have resulted from the lack of transmission of surface waves, which produce most of the violent motion of earthquakes (D. J. Varnes, oral commun., 1970), into the steep canyons along the river. At many outcrops along the canyons, we observed that loose rocks, ranging in weight from a few hundred pounds to many tons, were not disturbed on steep slopes, even in places where shaking was very noticeable. The earth tremor generated by the explosion was estimated to be equivalent to an earthquake of 5.5 Richter (surface-wave) magnitude 


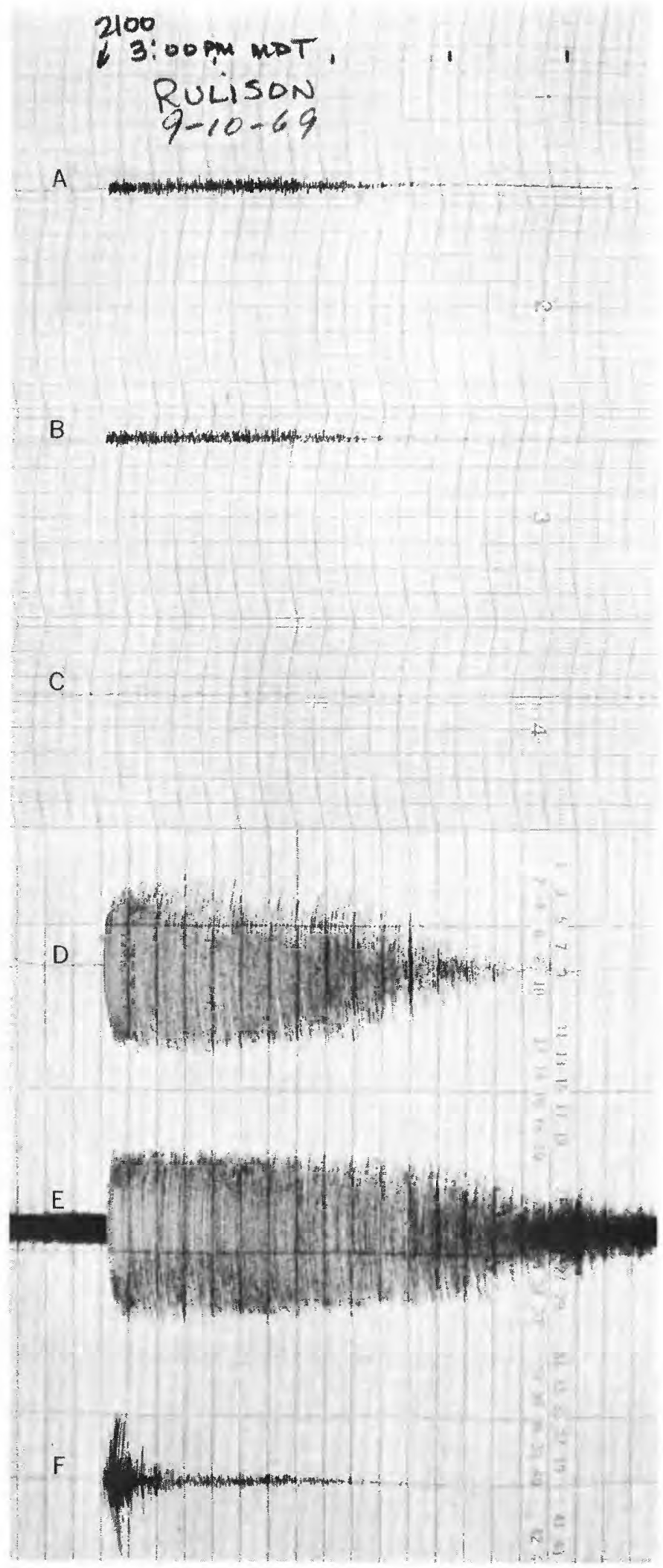

Figure 26. - Seismograms of the shock waves produced by RULISON nuclear explosion, near Grand Valley, recorded by the real-time system in the mobile network. Small early signals on traces $A$ and $B$ are static; signals on traces $A$ and $B$ at time of explosion are also static; $A$ was out of service, and $B$ was set at too low a gain to detect the blast. Preamplifier gains were: A, $7500 ; \mathrm{B}, 0.5$; C, 2.5 ; D, 7500; E, 30,000 with Willmore seismometer; and F', 50. All stations but E used EV-17 seismometers. Time progresses from left to right; 1-minute time intervals shown by chronograph ticks at top.

(Gauss, 1969), or of about 5.0 body-wave magnitude (Rutledge J. Brazee, written commun., 1969).

A nuclear explosion in Nevada was recorded in the Somerset district at about 8:32 a.m. m.d.t. on September 16,1969 . As shown in figure 27 , seismic waves from this explosion also were large enough to force many of the stations to the maximum output of the preamplifiers. Although the maximum shaking did not extend for as long a time as the waves from the RULISON explosion, the wave trains from the Nevada explosion were longer than those from the RULISON explosion.

The same explosion in Nevada was recorded by the fixed station at the Somerset mine (fig. 28). Much of the wave train also reached maximum output of this preamplifier, which had a gain of 7,500. The explosion imparted more energy to the district than was released by each of the local tremors shown in figures 17 and 18, which have less amplitude, shorter wave trains, and lower frequencies. Several local tremors occurred in or near the Somerset mine within several hours after the explosion, as did several small earthquakes outside the district. Records of these local tremors and earthquakes are shown in the lower part of figure 28 .

We recorded two small earthquakes at 3:06 a.m. m.d.t. (0906 G.m.t.) and at 9: 09 a.m. m.d.t. (1509 G.m.t.) on September 12 (fig. 29, trace A). The arrival times and wave envelopes of these tremors at the stations in the mobile network indicate that the sources were to the northwest, probably near the site of the RULISON explosion. The wave envelopes of these tremors, recorded by the fixed station, clearly indicate that the tremors occurred outside the district because of their long wave trains, low amplitudes, and low frequencies and because of the long separation between first-arriving compressional 
waves and late-arriving waves (fig. 30 ). We recorded none of the 16 earthquakes of magnitude less than 1 that were detected near the explosion site within the first 43 minutes after the blast (Hamilton and others, 1970, p. 1).

Similarities between the wave envelopes of the two small earthquakes (fig. 29) and the seismogram of the RULISON explosion by station F (fig. 26), recorded by the mobile network, also suggest that the sources were near the explosion site.

\section{CONCLUSIONS}

Earth tremors in the Somerset coal mining district are similar in occurrence pattern, depth of focus, and origin to many that occur in central Utah coal mining districts (Osterwald and others, 1971). We also recorded some types of tremors that were not found in Utah whose foci were outside the mining area. Foci of most of the larger tremors at Somerset were either beneath the actively worked part of the mine or beneath the intersection of several clastic dikes with the zone of steep dip in the southern part of the mine. Stress redistribution resulting from mining, as shown by distribution of tremor hypocenters (figs. 3,4 ) occurs within about 1 mile of the Somerset mine and as much as 6,000 feet below the mine.

A nuclear explosion 41 miles northwest of Somerset apparently resulted in larger peaks in the daily occurrence pattern of large tremors in the Somerset district and in an increased variation of such tremors. The explosion may also have resulted in a shift of tremors from a zone near the western part of the mine into an area from which pillars were being extracted. Surface effects of the explosion in the mine area were greatest at high topographic elevations and in surficial materials. The peak ground-motion parameters of shock waves from the explosion indicated that no undue forces were induced around the mine. Two small earthquakes, presumably centered near the site of the explosion, occurred 2 days later. A later explosion in Nevada also imparted much energy to the Somerset district.

Figure 27. - Seismograms of a nuclear explosion in Nevada, recorded by the real-time system in the mobile network in the Somerset district at about $8: 32$ a.m. m.d.t. on September 16, 1969. Parts of wave train at each station reached maximum output of preamplifier. Time progresses from left to right; 1-minute time intervals are shown by chronograph ticks at top.
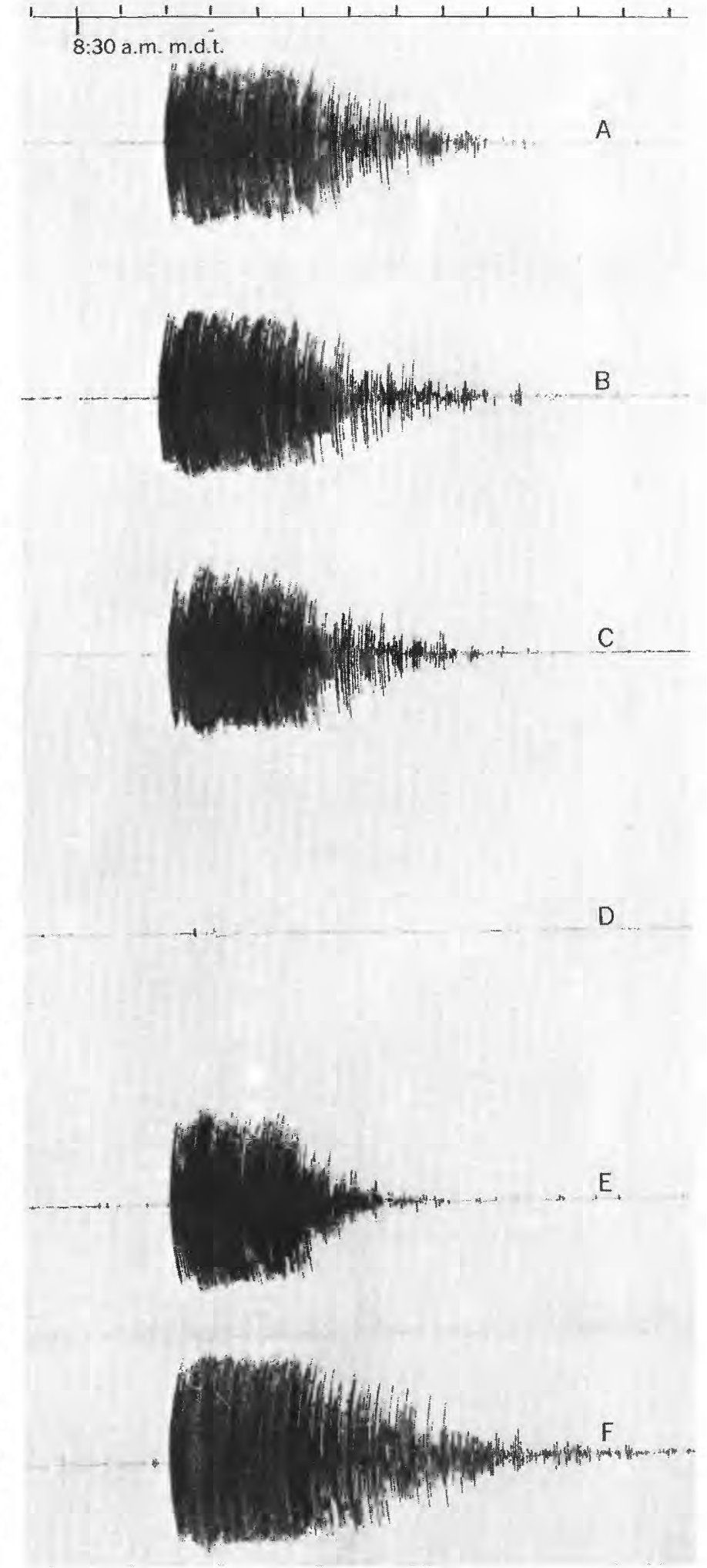


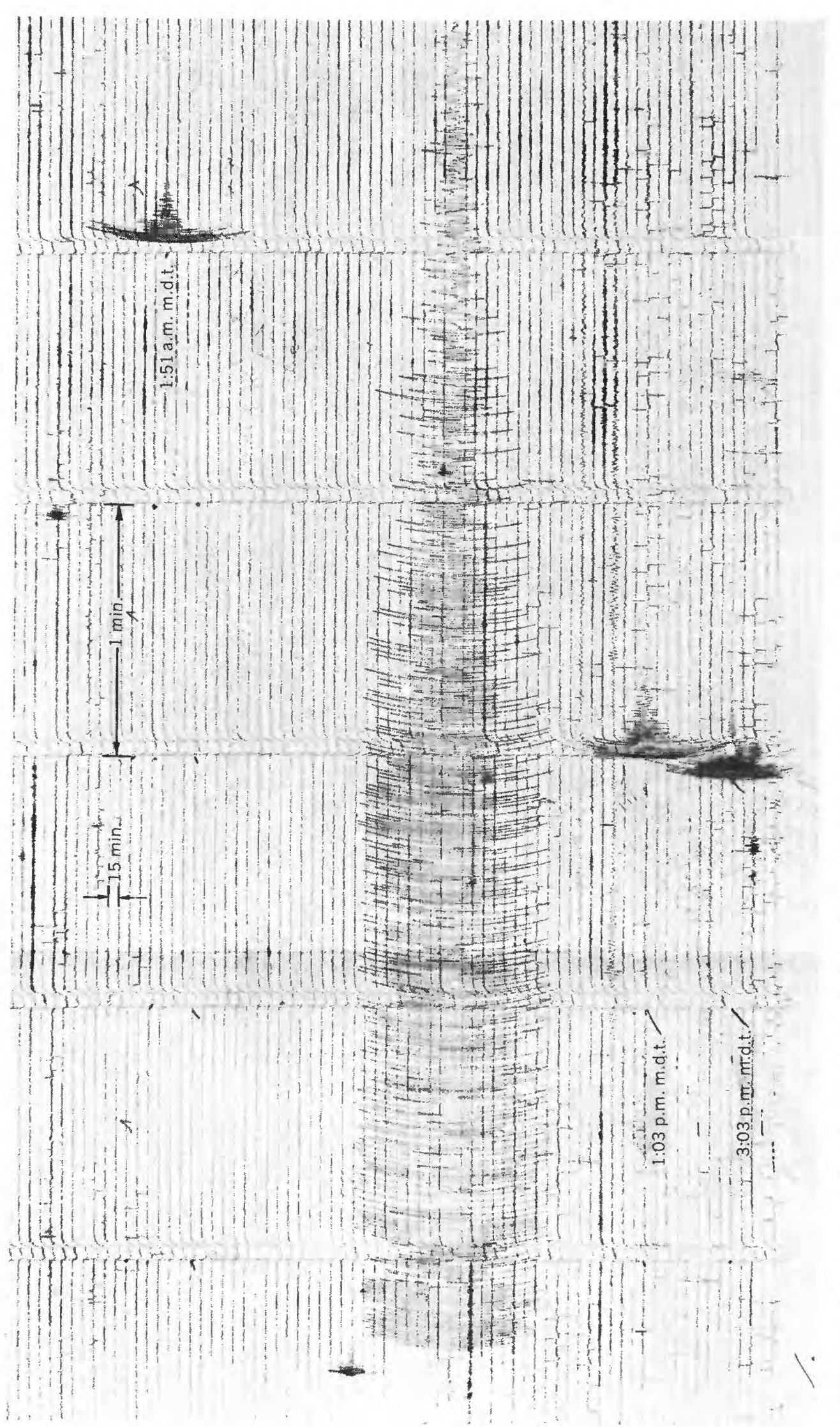

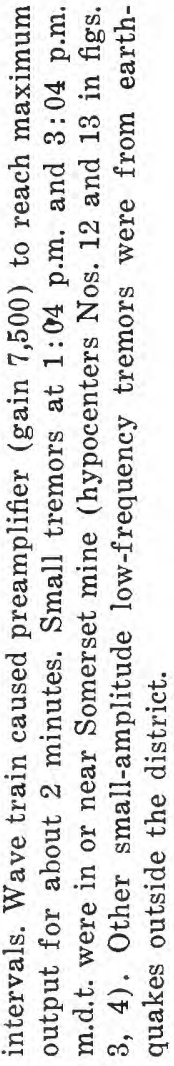

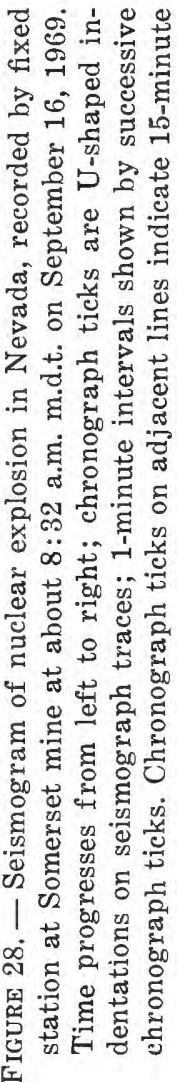




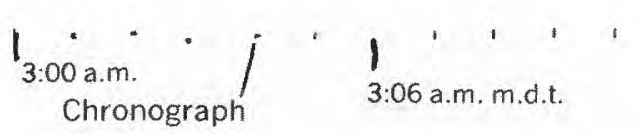

A
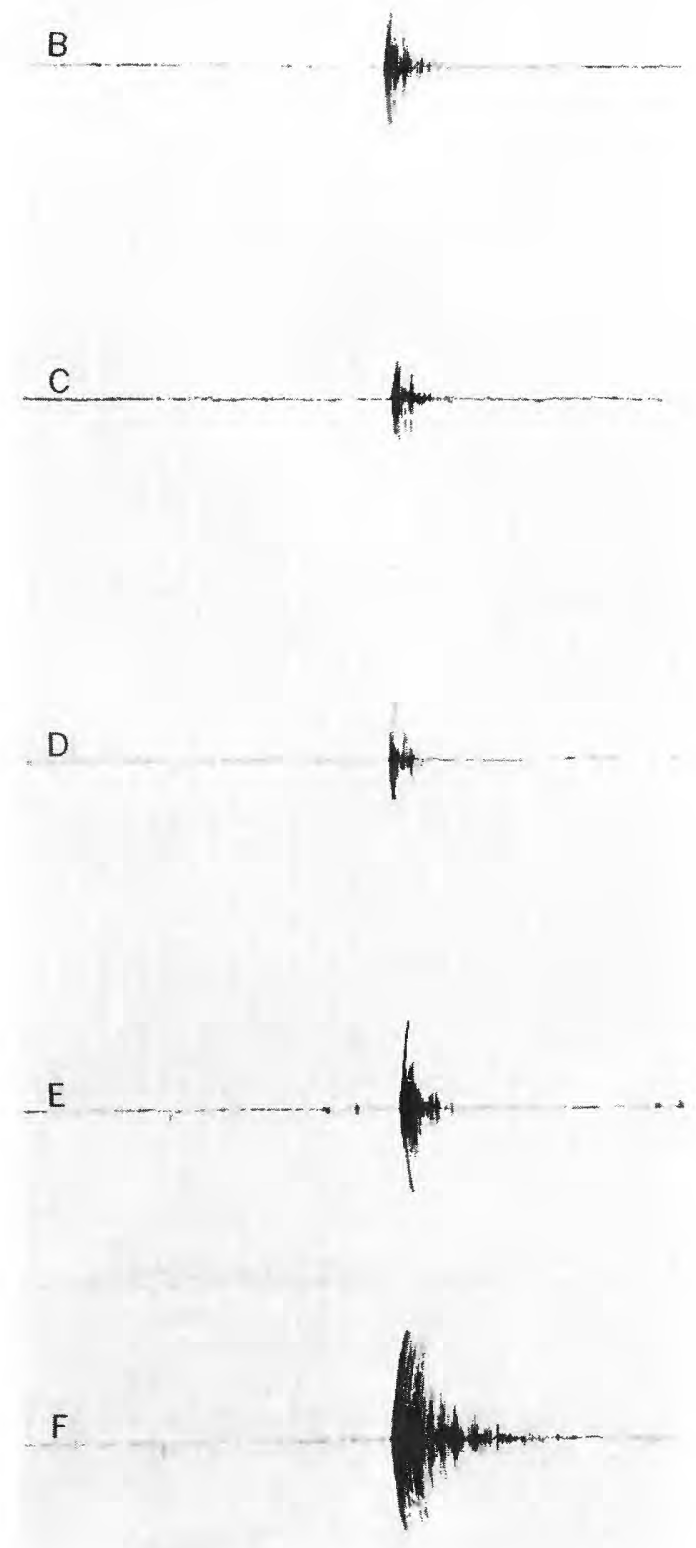

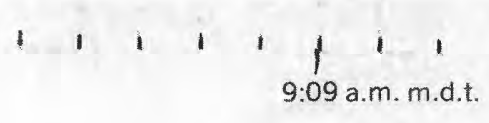

A.

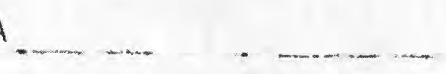

B

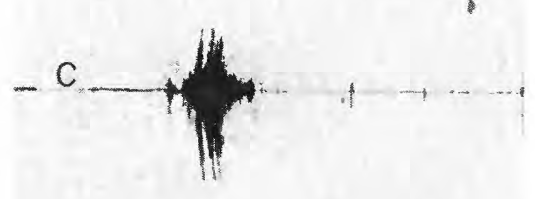

D
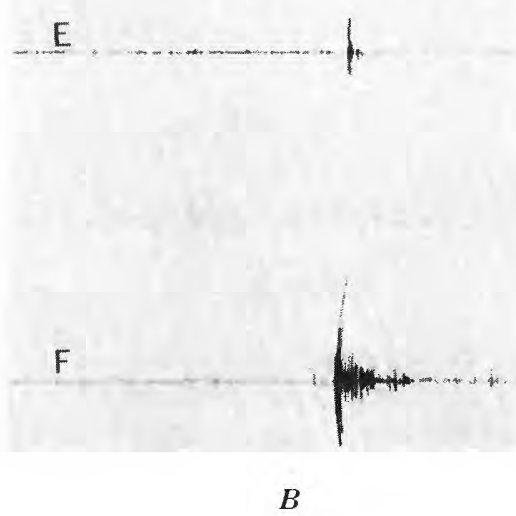

$A$

Figure 29. - Seismograms of two small earthquakes, recorded by the real-time system in the mobile network, presumably occurring near the site of the RULISON explosion: $A$, 3:06 a.m. m.d.t. (0906 G.m.t.) September 12, 1969; $B$, 9:09 a.m. m.d.t. (1509 G.m.t.) September 12, 1969. Letters indicate seismometer stations in figure 3; station $A$ was out of service. Time progresses from left to right; 1-minute intervals shown by chronograph ticks at top. 


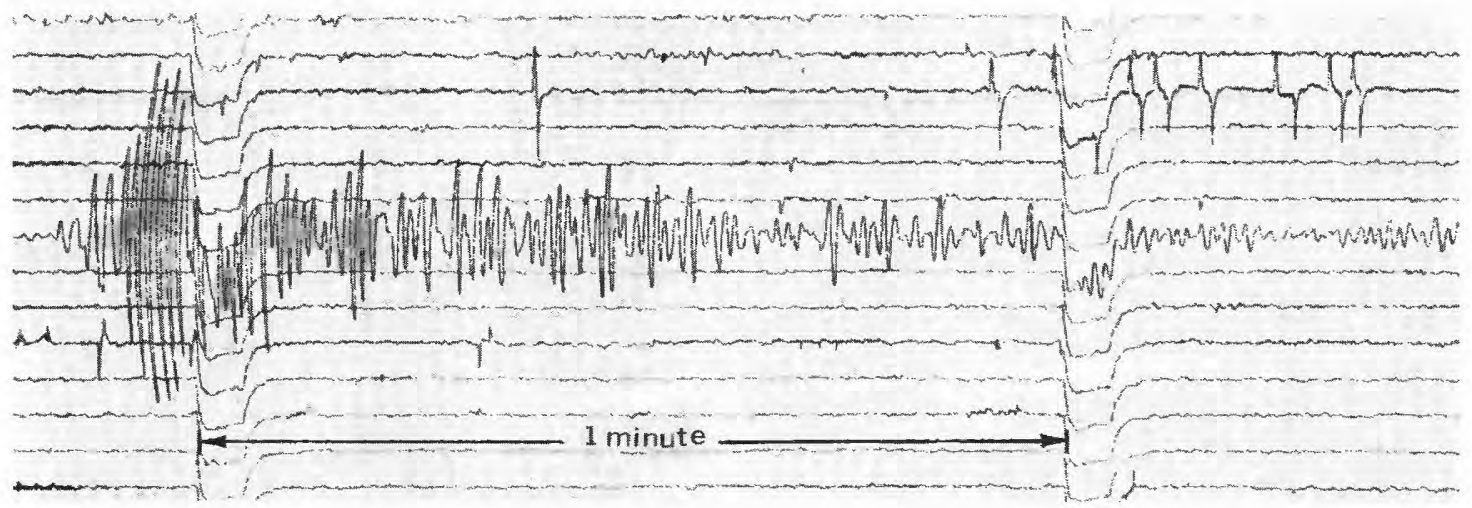

$A$

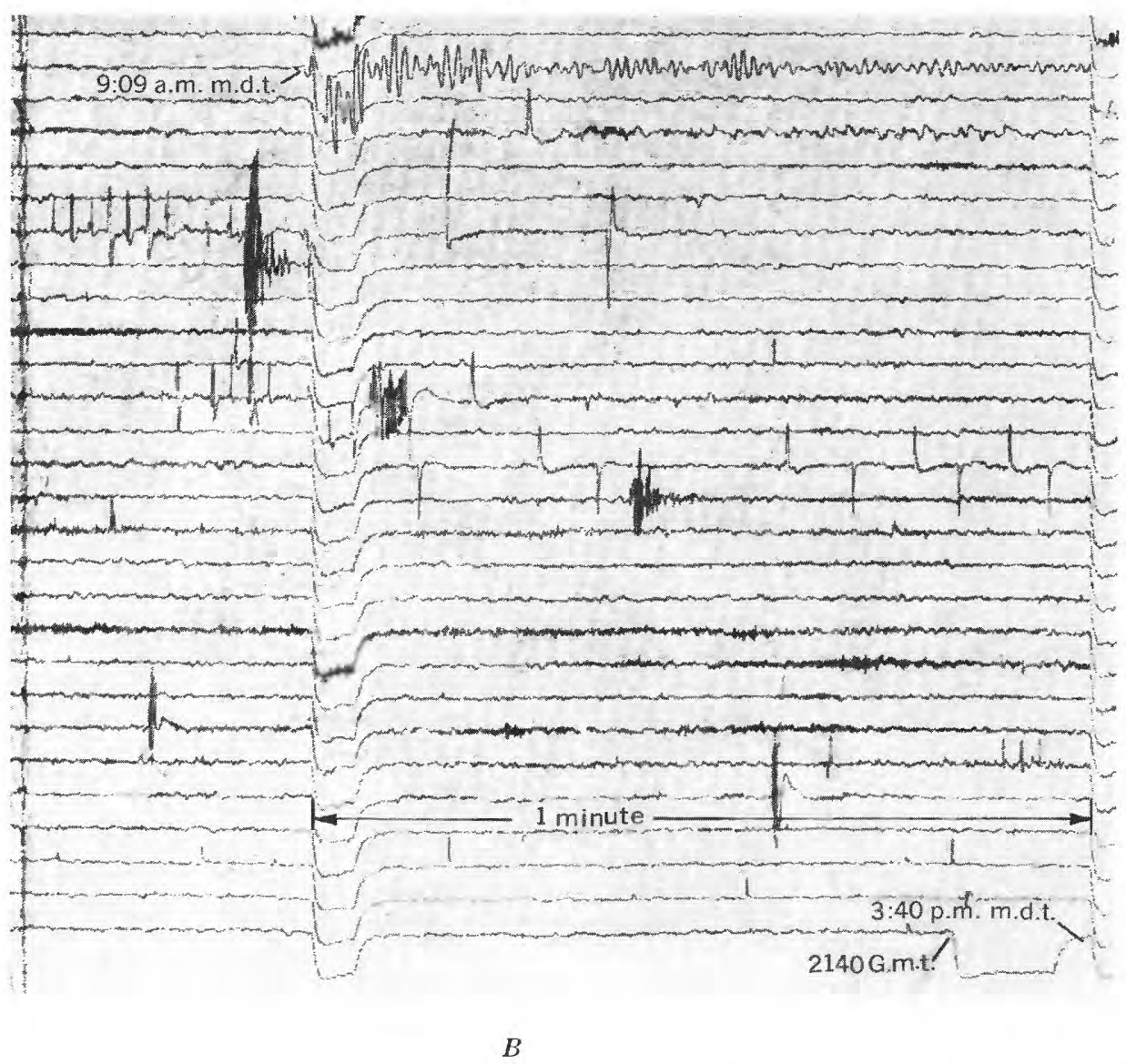

FIGURE 30. - Seismograms of two small earthquakes, recorded by the fixed station at the Somerset mine, presumably occurring near the site of the RULISON explosion: A, 3:06 a.m. m.d.t. (0906 G.m.t.) September 12,$1969 ; B, 9: 09$ a.m. m.d.t. (1509 G.m.t.) September 12, 1969. Time progresses from left to right; 1-minute intervals shown by chronograph ticks. Time correction between 2140 G.m.t. on local chronograph and 2140 G.m.t. from National Bureau of Standards radio station WWV is shown at bottom. 


\section{REFERENCES CITED}

Barnes, B. K., Dunrud, C. R., and Hernandez, Jerome, 1969, Seismic activity in the Sunnyside mining district, Utah, during 1967: U.S. Geol. Survey open-file report, 26 p.

Beebe, L. M., and Clegg, C. M., 1962, Rio Grande; mainline of the Rockies: Berkeley, Calif., Howell-North Press, 380 p.

Burbank, W. S., Lovering, T. S., Goddard, E. N., and Eckel, E. B., compilers, 1935, Geologic map of Colorado: U.S. Geol. Survey, scale 1:500,000.

Davies, David, 1968, Seismic methods for monitoring underground explosions: Stockholm, Sweden, Almquist and Wiksell, Stockholm Internat. Peace Research Inst., Stockholm Papers No. 2, 99 p.

Denman, Henry, 1903, Tenth biennial report of the inspector of coal mines of the State of Colorado, 1901-1902: Denver, Colo., Colorado Bur. Mines, 228 p.

Denver Post, 1969, Miners protest Rulison plan, slate work halt: Denver, Colo., Denver Post, Aug. 21, 1969, p. 37.

Gaskill, D. L., and Godwin, L. H., 1963, Redefinition and correlation of the Ohio Creek Formation (Paleocene) in west-central Colorado, in Short papers in geology and hydrology: U.S. Geol. Survey Prof. Paper 475-C, p. C35C38.

Gauss, G. G., 1969, Colorado N-quake registers at 5.5: Salt Lake City, Utah, Salt Lake Tribune, Sept. 11, 1969, p. $4 \mathrm{~A}$.

Hamilton, R. M., Smith, B. E., and Healy, J. H., 1970, Seismic monitoring of the RULISON underground nuclear explosion near Rifle, Colorado, on 10 September 1969: U.S. Geol. Survey open-file report, $6 \mathrm{p}$.

Johnson, V. H., 1948, Geology of the Paonia coal field, Delta and Gunnison Counties, Colorado: U.S. Geol. Survey Coal Inv. Map.
Lee, W. T., 1912, Coal fields of Grand Mesa and the West Elk Mountains, Colorado: U.S. Geol. Survey Bull. 510, $237 \mathrm{p}$.

Maberry, J. O., 1971, Sedimentary features of the Blackhawk Formation (Cretaceous) in the Sunnyside district, Carbon County, Utah: U.S. Geol. Survey Prof. Paper $688,44 \mathrm{p}$.

Osterwald, F. W., Bennetti, J. B., Jr., Dunrud, C. R., and Maberry, J. O., 1971, Field instrumentation studies of earth tremors and their geologic environments in central Utah coal mining areas: U.S. Geol. Survey Prof. Paper $693,20 \mathrm{p}$.

Osterwald, F. W., and Dunrud, C. R., 1966, Instrumentation study of coal mine bumps, Sunnyside district, Utah, in Central Utah coals-A guidebook prepared for the Geological Society of America and associated societies: Utah Geol. and Mineralog. Survey Bull. 80, p. 97-110.

Richter, C. F., 1958, Elementary seismology: San Francisco, Calif., W. H. Freeman and Co., 768 p.

Saile, Bob, 1969, Underground A-blast peril to coal mines feared: Denver, Colo., Denver Post, April 18, 1969, p. 31.

Tibbetts, B. L., Dunrud, C. R., and Osterwald, F. W., 1966, Seismic-refraction measurements at Sunnyside, Utah, in Geological Survey research 1966: U.S. Geol. Survey Prof. Paper 550-D, p. D132-D137.

U.S. Atomic Energy Commission, 1969, Effects evaluation for Project Rulison: U.S. Atomic Energy Comm., 33 p.; available only from U.S. Dept. Commerce Natl. Tech. Inf. Service, Springfield, Va. 22151, as Rept. NVO-43.

Yeend, W. E., 1969, Quaternary geology of the Grand and Battlement Mesas area, Colorado: U.S. Geol. Survey Prof. Paper 617, $50 \mathrm{p}$. 


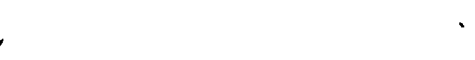

. 